\title{
Hâce Nevfidan Başkadınefendi ve Muhallefâtı
}

\section{Evren Gökçe*}

(ORCID: 0000-0001-5930-3020)

Makale Gönderim Tarihi

02.10 .2020
Makale Kabul Tarihi

16.03.2021

\section{Atıf Bilgisi/Reference Information}

Chicago: Gökçe, E., "Hâce Nevfidan Başkadınefendi ve Muhallefâtı”, VakanüvisUluslararası Tarih Araştırmaları Dergisi, 6/1 (2021): 139-177.

APA: Gökçe, E. (2021). Hâce Nevfidan Başkadınefendi ve Muhallefâtı. Vakanüvis-Uluslararası Tarih Araştırmaları Dergisi, 6 (1) , 139-177.

\section{Öz}

Osmanlı arşiv belgeleri vasıtasıyla valide sultanlar başta olmak üzere çeşitli statülerdeki saray kadınları birtakım incelemelere konu edilmişlerdir. Bu araştırmalar sayesinde Osmanlı üst sınıfına mensup olan saraylı kadınların yaşamları hakkında kaynaklara yansımamış veya yanlış bilinen hususlar hakkında doğru bilgiler edinilebilmektedir. Bu araştırmalar aynı zamanda imparatorluğun sosyo-ekonomik ve kültürel yaşamı hakkında önemli detaylar içermektedir.

Topkapı Sarayı'ndan Osmanlı arşivine intikal eden arşiv belgeleri arasında Sultan II.Mahmud'un başkadını Hâce (Hâcce-Hâciye) Nevfidan Başkadınefendi'ye ait bilgiler içeren defterler ve belgeler mevcuttur. Bu makalede söz konusu arşiv belgeleriyle birlikte ikincil kaynaklardan hareketle, Hâce Nevfidan Başkadınefendi'nin hayatı ve hayır faaliyetlerine değinilmiş, geride bıraktığı mal varlığı mercek altına alınmıştır. Böylece, bir Osmanlı hanedan mensubu örneğinden hareketle dönemin sosyo-kültürel yaşamı hakkında yapılmış çalışmalara katkı sağlanması hedeflenmiştir.

Anahtar Kelimeler: Osmanlı İmparatorluğu, Saray, Harem, Başkadınefendi, Muhallefât, Topkapı Sarayı Arşivi.

*Dr., evren1839@hotmail.com

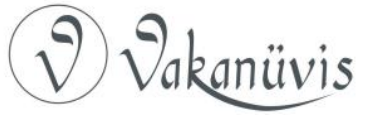




\title{
The Hâce (The Woman Pilgrimm) Nevfidan Başkadınefendi (The First Wife of The Sultan) and Her Inheritance
}

\begin{abstract}
Through Ottoman archive documents, firstly Valide Sultans and secondly other palace women became a matter of some researches. With the help of these studies, correct and some unknown information was obtained about that the lives of Ottoman women which member of an elite class. Besides to, these researches contain details about the social, cultural, and economic life of the Ottoman Empire.

At the transferred documents from Topkapı Palace to Ottoman Archive Foundation, there are some documents and books (heritage account and other books) which contain information of the Hâce Nevfidan Başkadınefendi who the wife of Sultan Mahmud and owner of the first wife rank (The Başkadınefendi) between he's wives. In this article with archive documents and other resources, the life, charity works, and heritage of the Hace Nevfidan Başkadınefendi studied and examined. Thus, moving from the pattern of an Ottoman dynasty member, making contribute aimed to the researches which about Ottoman social, cultural, and economic life.

Keywords: Ottoman Emprorship, Palace, The Harem, The First Wife of The Sultan, Inheritance, The Topkapı Palace Archive

\section{Giriş}

XIX. yüzyılın ilk yarısının sonlarında itibaren Osmanlı imparatorluğunda başta saray olmak üzere başkent İstanbul ve ülkenin diğer yerlerinde batılı yaşam tarzı etkili olmaya başlamıştır. Bu yaşam tarzı özellikle saray kadınları arasında revaç bularak önceki dönemlerde görülmeyen derecede alışveriş ve harcamalar yapılmaya başlanmıştır. Özellikle Kırım savaşından sonra artan ve bazen aşırı dereceye varan harcamalar, devletin 1876 yılında yaşadığı mali buhranda önemli pay sahibidir. Dönemin kaynaklarında hanedan mensupları ve saray kadınlarının bu konuda sergiledikleri yaklaşım ciddi eleştirilere tabi tutulmuştur. Hanedan mensupları ve saray kadınlarının vefatlarından sonra tutulan muhallefât defterleri sayesinde söz konusu dönemin sosyo-ekonomik ve kültürel açıdan daha iyi incelenmesi mümkün olmaktadır.
\end{abstract}

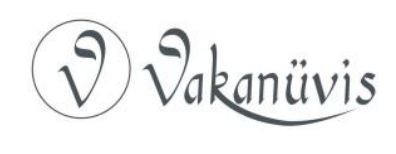


XIX. yüzyılın ilk yarısında sarayda bulunmuş padişah eşlerinden birisi Sultan II. Mahmud'un Başkadınefendisi Hâce Alîcenâb Nevfidan Başkadınefendi'dir. Osmanlı sarayında valide sultandan sonra gelen en üst mevkide bulunan Nevfidan Başkadınefendi, padişaha beş çocuk doğurmuş, ancak bunlardan hiçbirisi yaşamamıştır. Sultan II. Mahmud'un vefatından sonra bir süre daha sarayda yaşayan Nevfidan Başkadınefendi Sultan Abdülmecîd'den aldığı izinle kutsal toprakları ziyaret etmiş ve Hâce unvanına sahip olmuştur. Hanedan ve harem kadınları arasında hacca giden fazla olmadığı için bu unvanla özdeşleşmiş ve sonraki hayatında bu unvanla anılmıştır.

Hâce Nevfidan Başkadınefendi aynı zamanda hanedanın tanınmış ismi Âdile Sultan'ın manevî annesi olarak bilinmektedir. Çocuğu olmaması sebebiyle Sultan II. Mahmud Başkadınefendi'ye annesi olmayan kızı Âdile Sultan'ı teslim etmiştir. Başkadınefendi Âdile Sultan'ı büyütmüş ve yetiştirmiş, bir süre Âdile Sultan'a tahsis edilen sarayda birlikte yaşamışlardır. Âdile Sultan Nevfidan Başkadınefendi'den ayrıldıktan sonra Başkadınefendi'ye Hazîne-i Hassa tarafından Beylerbeyi'nde bir sâhilhâne alınmış ve ikamet etmesi için döşenmiştir. Ancak Başkadınefendi burada fazla yaşayamamış ve kısa süre sonra vefat etmiştir. Vefatından sonra sâhilhâne Hazine-i Hassa tarafından yapılan döşeme masraflarını karşılaması şartıyla eski Serasker Rızâ Paşa'ya verilmiştir. Böylece sâhilhâne Rızâ Paşa'nın mülkü olmuştur. Başkadınefendi'nin sahilhânede bulunan muhallefâtı ise sayılarak kayıtlara geçirilmiş, kısa bir süre sonra Hazîne-i Hassa tarafından satılmıştır. Bu sayım ve satışa dair kayıtlar, Topkapı Sarayı'ndan Osmanlı Arşivi'ne intikâl eden Muhallefât Defterleri'nde bulunmaktadır. Bu çalışmada Nevfidan Başkadınefendi'nin hayatı, faaliyetleri ve son yıllarını geçirdiği sahilhânesine dair detaylara kısaca yer verilmekle birlikte, esas olarak geride bıraktığı muhallefâtı söz konusu defterlerden hareketle mercek altına alınmıştır. Böylece, Osmanlı sarayında en üst mevkilerden birisine gelmiş bir saray kadının mal varlığı vasıtasıyla dönemin sosyo-kültürel ve ekonomik hayatına dair izlenimler elde edilmeye çalışılmıştır.

\section{Osmanlı Saray Hiyerarşisinde Başkadınefendilik}

Osmanlı sarayında padişahın yaşamını sürdürdüğü yer olan, kendine özgü bir yapısı ve işleyişi olan haremin (Harem-i Hümâyûn) temelinde

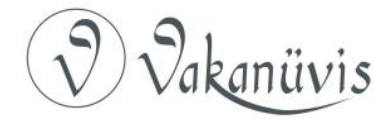


hiyerarşik bir yükselme sistemine dayanan kurumsal bir yapı bulunmaktaydı. Çalışanlarının ve sakinlerinin çeşitli derece ve unvanlar taşıdığı, bu derece ve unvanlar doğrultusunda yaşamlarının düzenlendiği haremde, söz konusu hiyerarşik sistemin bir sonucu olarak, valide sultanlardan sonra padişah eşleri gelmekteydi. Diğer harem kadınlarından ayrı bir yer ve statüde olan padişah eşleri, geleceğin valide sultan adaylarıydı. Türkçe bir kelime olan Hâtûn kelimesinden bozma olarak verilen Kadın veya Kadınefendi unvanını yalnızca onlar tarafından taşınmaktaydı. ${ }^{1}$

Harem kurumunun yapısını şekillendiren bu hiyerarşide, kadınlık mevkisinin altında Gedikliler adı verilen başka bir sınıf mevcuttu. Kadınlar veya Kadınefendi'ler padişahın özel hizmetini gören bu sınıf arasından seçilmekteydiler. Bir cariyenin gedikliler sınıfına girdiği anda padişahın eşi olma şansını yakalaması mümkündü. Nitekim aralarında padişahın ilgisini çekenlere Hasodalık veya ikbâl unvanı verilirdi. ikballer arasında padişahın özel ilgisine mazhar olan Başikbal unvanını kazanır, bir Kadınefendi'nin vefatı veya eski saraya sürgünü durumlarında bu mevkiye geçerdi. Harem hakkında yaptığı çalışmalarla tanınan Çağatay Uluçay, verâset sisteminin değişmesinden sonra şehzâdelere maiyetlerinde bulunan cariyelerle münasebet kurma izni verildiğini, Kadınefendi'lerin genellikle bu cariyeler arasından çıktığını belirtmektedir. Pakalın'a göre ise önceleri Kadın unvanı taşıyan padişah eşlerine, Sultan Abdülmecid zamanında nikah usulüne geçilmesi üzerine Kadınefendi denmeye başlanmıştı. Yukarıda değinilen aşamaları geçerek padişah eşi mevkisine gelen Kadınefendi'lerin sayısı dördü aşmazdı. Ayrıca bir ikbâlin Kadınefendi olabilmesi için çocuk doğurması ve padişahın sevgisini kazanması gerekmekteydi. Kadın-Kadınefendi tabiri sadece padişahın nikahlı eşlerine aitti. Veliahdın ve şehzâdelerin gözdelerine, çocuklu olsalar bile Kadınefendi unvanı verilmezdi. ${ }^{2}$

\footnotetext{
${ }^{1}$ M.Çağatay Uluçay, Harem, Ötüken Yayınları, İstanbul, 2013 s.92.

2 Uluçay, a.g.e.,s.95; M.Zeki Pakalın, Osmanlı Tarih Deyimleri ve Terimleri Sözlüğü C.II, Birinci Baskı, İstanbul, 1993, s.127. Uzunçarşılı padişah eşlerinin kadın-kadınefendi ile birlikte haseki unvanını da taşıdıklarını, bu unvanın erkek veya kız çocuk doğuran padişah eşlerine verildiğini belirtmektedir. İsmail Hakkı Uzunçarşılı, Osmanlı Devletinin Saray Teşkilatı, TTK. Yayınları, Ankara, 1988, s.148, 152.
}

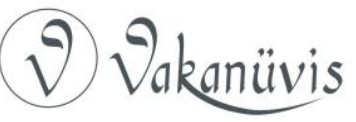


Kadınefendi'ler harem hiyerarşisi dahilinde kendi aralarında sıraya tabiydiler. İçlerinde kıdemli olanlar Başkadın veya Başkadınefendi ünvanıyla anılırdı. ${ }^{3}$ XVII. yüzyıl sonunda İstanbul'da bulunan Fransız ressam Castellan seyahatnamesinde Başkadınefendi'den "Premiere Khatun-Sultan Favorite" gibi tabirlerle bahsetmektedir. Başkadınefendi'yi takiben mevki itibarıyla ikinci Kadın ve diğer padişah eşleri gelmekteydi. Yukarıda vurgulandığı gibi Kadınefendi sayısı dört veya altıyı geçmezdi. Ancak bazı kaynaklara göre Kadınefendi'lerin sayısı evvela yedi iken II. Mahmud zamanında yedinci kadınlığın lağvıyla altıya, Sultan Abdülmecîd zamanında ise altıncı kadınlığın lağvıyla beşe inmiştir. ${ }^{4}$

Osmanlı sarayını oluşturan diğer bölümler gibi işleyişinde kural, gelenek ve uygulamaların yer aldığı haremde dikkat edilen hususlardan birisi, harem halkını oluşturan kadınların giyimleriydi. Harem mensupları bulundukları mevkiye göre bazı giysileri giyme hakkına sahip olurlardı. Bunlardan birisi olan Başkadınefendi de kendine has bir giysiye sahipti. Kaynaklarda belirtildiğine göre başında bağtak denilen hotozları gayet güzel renklerden ve tepesi sivri olarak yapılan bir başlık taşımaktaydı. Başlığın üzerinde kıymetli taşlar, çiçekler ve tüylerle birlikte, bir kısmında tepelik bulunuyordu. Uzun saçlar topuz yapılarak bu başlığın üzerine yerleştirilirdi. Boyunlarında gayet kıymetli gerdanlıklar bulunmakta olup gerdanlıklar inci ve elmastan yapıldığı gibi bazen altın paradan yapılırdı. Kulaklarda küpeler mevcuttu. Giysi olarak omuz sırt ve yakaları kürklü zemini sevaî bir elbise giyilirdi. Bir kısım elbiselere tepe başı denirdi. Bunlar üzeri som sırma işlemeli gayet ağır ipek kumaştan yapılmaktaydı. Altın işlemeli sevaîler daha ziyade tercih edilirdi. Simsimiye adı verilen ağır kumaş türü de bu işte kullanılırdı. Bursa ve İstanbul kârhânelerinden gelen kumaşlar saray

\footnotetext{
3 Örneğin Sultan Abdülmecîd'in başkadını Servetsezâ Başkadınefendi'nin mühründe ünvanı "Devletlû Başkadın Servetsezâ Kadınefendi Hazretleri" olarak belirtilmektedir. Necdet Sakaoğlu, Bu Mülkün Kadın Sultanları, Alfa Tarih Yayınları, İstanbul, 2015, s.574. 4 Serap Yılmaz, "Saraylı Bir Kadının Gardrobu (19.yy)" XIII. Türk Tarih Kongresi, C.III, TTK. Basımevi, 1998, s.1080; Uzunçarşılı, a.g.e., s.148; Pakalın, a.g.e., s.127; Şehsüvaroğlu'nun belirttiğine göre Sultan Abdülmecid zamanında Beşiktaş sahilsarayındaki başkadınefendi odasına Çinili Oda ismi verilmekteydi. Haluk Y Şehsüvaroğlu, Boğaziçi'ne Dair, Türkiye Turing ve Otomobil Kurumu Yayını, İstanbul, 1982, s.125-126.
}

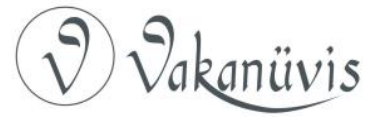


terzihanelerinde dikilirdi. Kadın kuşağı adı verilen bir örtü göbek üzerine bağlanırdı. ${ }^{5}$

Başkadınefendiler diğer harem mensupları gibi vazifeleri veya mevkileri karşılığında belirli miktarda gelire sahiplerdi. Tanzimât'ın ilânından sonra bu gelirler maaşa çevrilmişti. Bu tarihlerde devlet tek hazine ve tek bütçe anlayışı doğrultusunda geleneksel çoklu hazine sistemi terk edip tek bir hazine oluşturmuş ve bu merkezi hazineye Malîye Hazînesi adı verilmişti. Padişah ve saraya ait harcamaların ödenmesi için padişaha maaş bağlanması amacıyla H.1256/M.1840 tarihinden itibaren Malîye Hazînesi'nden Darbhâne'ye 12.500 kese verilmesi kararlaştırılmıştı. Bu meblağ Darbhâne kanalıyla tamamen padişahın şahsî masraflarını karşılamak üzere ayrılan Ceyb-i Hümâyûn Hazînesi'ne aktarılmaya başlanılmıştı. Ceyb-i Hümâyûn Hazînesi 1846 tarihinden itibaren sonra Hazîne-i Hassa adıyla anılmaya başlamıştı. Hazine-i Hassa'nın gider kalemlerinden birisi saray görevlileriyle harem mensuplarına tahsis edilen maaşlar idi. ${ }^{6}$

Sultan II. Mahmud'un vefatından önce başlayan merkezî hazine ve maaş uygulaması ile birlikte altı Kadınefendi'si için maaş tahsisine geçilmişti. Ancak kıdem ve mevki olarak diğer padişah eşlerinden ileride olan Başkadınefendi, beş Kadınefendi ile birlikte aynı maaşı almaktaydı. Sultanın altı Kadınefendi'sinin maaşları aylık 4.000 guruş olarak belirlenmişti. Bununla birlikte gelirleri maaşlarıyla sınırlı kalmıyordu. Hepsine çeşitli isimler altında birtakım başka gelirler tahsis edilmişti. Bu tahsisât 16.000 guruş değerinde olup yıllık 64.000 guruşa ulaşmaktaydı. ${ }^{7}$

Başkadınefendi ve diğer Kadınefendi'lere sağlanan imkanlardan biri de sadece saray dahilinde değil, istedikleri yerlerde yaşayabilmeleriydi. Nitekim XVIII. yüzyıldan sonra gerek tahttaki padişahın gerek eski padişahın Kadınefendi'leri tercihlerine göre saray dışında ikâmet edebiliyorlardı. Hali vakti yerinde olmayan eski Kadınefendi'ler ise kabul edilirse haremde veya kendilerine gösterilen yerde iskân ediliyorlardı. Nitekim Hâce Nevfidan Başkadınefendi'de, manevî evladı Âdile

\footnotetext{
${ }^{5}$ Yılmaz, a.g.m., s.1076

${ }^{6}$ Arzu Terzi, Hazine-i Hassa Nezâreti, TTK. Yayınları, Ankara, 2000, s.2, 17-18, 124.

${ }^{7}$ Bu tahsisâtlar Terzi tarafından verilen bir listede "Sayfiye, Kasımiye, Muharremîye, ve Îdiyye olarak görülmektedir. Arzu Tozduman Terzi, Bezmialem Valide Sultan, Timaş Yayınları, İstanbul, 2018, s.46
}

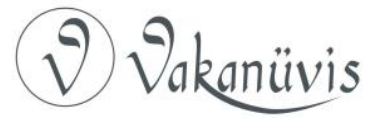


Sultan'dan ayrıldıktan sonra Hazîne-i Hassa tarafından satın alınan bir sahilhâneye yerleştirilmişti. ${ }^{8}$

\section{Hâce Nevfidan Başkadınefendi}

Arşiv belgelerinde kendisinden "Hâce Başkadınefendi-Başkadın Hâce Nevfidan Kadınefendi- El-Hâce Nevfidan Kadınefendi" gibi ifadelerle bahsedilen ${ }^{9}$ Hâce Nevfidan Başkadınefendi, hayatının bir döneminde Sultan II. Mahmûd'un Başkadınefendi'si olarak Topkapı sarayında yaşamıştır. Sultan II. Mahmud'un vefatından sonra Hâc ibadetini yerine getirmiş ve döndüğü İstanbul'da H.15 R.Ahir 1272/M. 25 Aralık 1855 tarihinde vefat etmiş ve eşi Sultan Mahmud'a ait türbenin bir odasına defnedilmiştir. ${ }^{10}$ Hâc vazifesini yerine getirmesi onu hanedân mensupları arasında ayrı bir yere koymuş ve vefatına kadar Hâce (Hâcce-Hâciye) gibi sıfatlarla anılmıştır. Bu özelliğine rağmen Hâce Nevfidan Başkadınefendi hakkında kaynaklarda fazla bilgi bulunmamaktadır.

\footnotetext{
8 BOA.TS.MA.e...603/69; Uluçay, a.g.e. s.94-95.

9 BOA. A.MKT.115/15; TS.MA.e...603/69; C..EV..537/27126, vd. Söz konusu isimlerin yanı sıra Öztuna Nevfidan Başkadınefendi'nin aynı zamanda Pertev Piyâle isimlerini taşıdığını zikretmektedir. Nitekim Sultan Abdülaziz bir yata Pertev Piyale ismini vererek üvey annesi olan Başkadınefendi'nin hatırasını yad etmiştir. Yılmaz Öztuna, Devletler ve Hanedanlar, C.II, Kültür ve Turizm Bakanlığı Yayınları, Ankara, 2005, s.254; Osmanlı hanedânı üzerine bir eser kaleme alan Alderson'un Nevifidan ile birlikte zikrettiği Nevifedâ isimleri yanlıştır. Sakaoğlu Alderson'dan nakille Başkadınefendi'nin Nevifedâ olarak anıldığını bilgisini vererek aynı yanlışı tekrarlamaktadır. A.Dolphin Alderson, Bütün Yönleriyle Osmanlı Hanedanı, Birinci Baskı, İz Yayıncılık, İstanbul, 1998, s.277; Sakaoğlu, a.g.e., s.546.

10 Sicill-i Osmânî'de Başkadınefendi'den "Hâcce" ve "Nevfidan Kadın" olarak bahsedilmektedir. Mehmed Süreyya, Sicill-i Osmânî, C-I, Haz. Nuri Akbayar, Tarih Vakfı Yurt Yayınları, İstanbul, 1996, s.32; 1839 tarihinde Ohannes ve Bogos Dadyan tarafından yapımı tamamlanan sekizgen planlı ampir üsluplu türbeye sağlı sollu odaları olan bir koridordan girilmektedir. Soldaki oda Hace Nevfidan Başkadınefendi'nin türbesi olarak adlandırılmaktadır. Civan tarafından hazırlanan eserde Başkadınefendi'nin sandukasının bulunduğu yer "Nef-i Fida Türbesi" şeklinde yine yanlış olarak belirtilmiştir. Celil Civan, İstanbul'un Yüz Türbesi, İstanbul Büyükşehir Belediyesi Kültür AŞ. Yayınları, İstanbul, 2013, s.71; Hâce Nevfidan Başkadınefendi'nin yanına ilerleyen yıllarda şehzâde Mehmed Selim Efendi defnedilmiştir. "Geçende vefât idüb cennetmekân Sultan Mahmûd Hân-ı sânî tâbe serahû hazretlerinin ittisâlinde Hâce Başkadınefendi türbe-i şerîfine defn olunmuş olan şehzâde Mehmed Selîm Efendi hazretleri...H.20 Zilhicce-R.1 Nisan 1284/M.13 Nisan 1868" BOA.TS.MA.e...601/75.
}

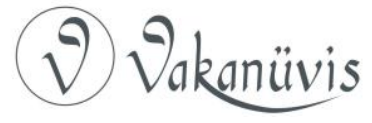


Sultan II. Mahmud'un eşleri arasında Fâtıma ve Âlîcenâb kadınlardan sonra gelen Nevfidan Başkadınefendi, 1793 tarihinde doğmuş, Sultan II. Mahmud'un vefatından 16 yıl sonra 62 yaşında vefat etmiştir. Uluçay, milliyet ve hayatı hakkında fazla bilgi bulunmayan Başkadınefendi'nin sevilip sayılan ve itibar sahibi bir şahsiyet olduğunu, bu durumun Sultan Abdülmecîd tarafından hacca gitmesine izin verilmesinden anlaşıldığını belirtmektedir. Aldığı izinle M.1842 tarihinde hacca giden Başkadınefendi, hâcdan dönüşünden sonra on üç sene daha yaşamış ve o devirde valide sultan olan Bezmîalem Valide Sultan'ın vefatını takiben üç yıl sonra hayatını kaybetmiştir. Mühründe "Sultan Mahmud cennetmekânın devletlû Hâciye Nevfidan Başkadın hazretleri" ibaresi bulunmaktadır. ${ }^{11}$

Başkadınefendi Sultan II. Mahmud'a çeşitli tarihlerde dört kız ve bir erkek çocuk doğurmakla birlikte bu çocuklardan hiçbirisi yaşamamıştır. Dört kızından M.1809 ve M.1810' da doğanlar Fâtma, M.1813 ve M.1815 tarihlerinde doğanlar ise yine ortak şekilde Emîne isimlerini taşımaktaydı. Başkadınefendi'nin tek erkek çocuğu olan Şehzâde Osmân ise kızlardan birinci Emîne Sultan'ın doğduğu 1813 tarihinde dünyaya gelmiş, ancak kardeşleri gibi küçük yaşta vefat etmiştir. Bununla birlikte Başkadınefendi'nin çocuklarla olan ilişkisi kesilmemiştir. M.1832 tarihinde ileride Osmânlı hanedanının tanınmış şahsiyetlerinden olacak olan Âdile Sultan, annesi Zernigâr Kadınefendi'nin vefatıyla üzerine II. Mahmud tarafından Başkadınefendi'ye teslim edilmiştir. ${ }^{12}$ Hanedân mensupları arasında divan sahibi tek sultan olan Âdile Sultan, şiirlerinde Başkadınefendi'nin hali ve ahlakı güzel, takva sahibi bir insan olduğunu, vefatıyla kendisini yetim bıraktığını ifade etmektedir. ${ }^{13}$

Hâce Nevfidan Başkadınefendi eşi Sultan II. Mahmud'un vefatından sonra bir süre haremde yaşamaya devam etmiştir. Nitekim Sultan

11 Öztuna, a.g.e., s.254; M.Çağatay Uluçay, Haremden Mektuplar, Ötüken Yayınları, İstanbul, 2012, s.111,113.

12 Öztuna, a.g.e., s.254; Sakaoğlu, Başkadınefendi'nin ilk çocuğu olan Fatma Sultan'ın aynı zamanda analığı yani üvey annesi olabileceği bilgisini vermektedir. Sakaoğlu, a.g.e., s.546.

${ }^{13}$ Âdile Sultan divanında Başkadınefendi'den "Sonra oldu Nevfidan Kadın bana/ Kendi evladı gibi sâdık ana /Kimseye çeşmim yaşın sildirmedi/Validem olmadığın bildirmedi" dizeleriyle bahsetmektedir. Arif Kolay, "Hayırsever, Dindar Nazik ve Şaire Bir Padişah Kızı: Adile Sultan”, Akademik Incelemeler Dergisi, C.12, S.2, 2017, s.8.

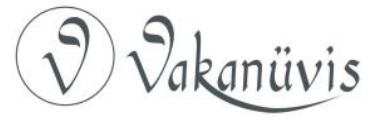


Abdülmecîd'in cülusundan kısa bir süre sonra H.1255 Cemâziyülevvel ayının başından itibaren (M.13 Temmuz 1839) Başkadınefendi'nin yanı sıra Sultan Mahmud'un ikinci ve altıncı Kadınefendi'leri de çocukları olduğu için haremde kalmaya devam etmişlerdir. ${ }^{14}$ Bununla birlikte yukarıda belirtildiği gibi ilerleyen tarihlerde Başkadınefendi için Boğaz'da bir sahilhâne satın alınmış ve buraya yerleştirilmiştir. H.10 Şa'bân 1270/M.8 Mayıs 1854 tarihli bir belgeye göre, Beylerbeyi semtindeki sahilhâne vefat eden Nafiz Paşa'nın varislerinden satın alınıp padişahın emriyle tefrîş edilerek düzenlenmiş, ayrıca Başkadınefendi'nin yerleşmesine kadar sahilhâneyi beklemek üzere bir görevli tayin edilmiştir. ${ }^{15}$

Hâce Başkadınefendi'ye tahsis edilen bu sahilhânede, yapılan tefrîşten sonra başka yenilemeler de yapılmıştır. H.3 Safer 1271/M.26 Ekim 1854 tarihli bir belgeye göre, Başkadınefendi sahilhânesi ile birlikte diğer bazı sahilhânelerin yazlık döşemeleri (sayfiyye mefrûşâtı) yenilenmiştir. H.27 Cemâziyülâhir 1271/M.17 Mart 1855 tarihli başka bir belgede sahilhânenin kışlık döşemelerinin (şitâiyye mefrûşâtı) yenilendiği belirtilmektedir. H.12 Rebiulâhir 1271/M. 2 Ocak 1855 tarihli diğer bir belgede ise sahilhâne ve diğer bazı yerler için Gördes işi (Gördüskârî) nihalîlerin döşenmesi emri verildiği, ancak Topkapı sarayında bulunan nihalîler bu iş için yeterli olmadığı için yenilerinin alınmasına karar verildiği görülmektedir. ${ }^{16}$

Hâce Nevfidan Başkadınefendi'ye ikâmeti için satın alınan sahilhâne ile birlikte geçimini temin etmesi için kendisine tahsis edilmiş birtakım gelir kaynaklarına dair detaylara arşiv belgelerinde rastlanmaktadır. Başkadınefendi'nin diğer saraylılar gibi esas ve temel gelirini Tanzimât sonrasında yapılan düzenlemelerden sonra kendisine verilen maaş oluşturmaktadır. Bu maaş yılda dört taksitle kendisine verilmekte, "Kasımîye, Muharremîye" vb. isimlerle anılmaktadır. Nitekim H.16 Safer

\footnotetext{
14 Terzi, Bezmialem Valide Sultan, s.46.

15 "Devletlû atıfetlû El-Hâce Başkadınefendi hazretlerine mübâyaa olunmuş olan Beylerbeyinde kâin Nafîz Paşa merhûmun sahilhânesi..." BOA.TS.MA.e...603/69

${ }^{16}$ BOA.TS.MA.e...603/76, 603/80, 603/82; H.1270/M.1854 tarihli bir hesap defterinde ise sahilhânede yapılan yenilemelere dair ayrıntılar mevcuttur. BOA.TS.MA.d...7916/19.
}

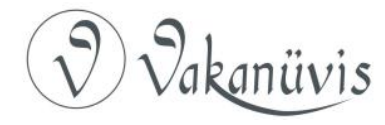


1271/M.8 Kasım 1854 tarihli bir belgeye göre Başkadınefendi'nin "rûz-ı Kasımîyesi" 5.000 guruş tutarındadır. ${ }^{17}$

Düzenli olarak taksitler halinde aldığı maaş ile birlikte, Başkadınefendi'ye ait gelir kaynakları arasında Evkaf-ı Hümâyûn tarafından tahsis edilen bazı meblağlarla, eshâm gibi birtakım kaynaklar da mevcuttur. H.1251/M.1835 tarihli bir belgeye göre aynı yılın Muharrem ayı ile (Nisan) Zilhicce (Mart) ayı arasında Evkaf-ı Hümâyûn'a ait Silivri kazâsındaki bir vakıf değirmenin aylık 120 akçeden yıllık 12 guruşluk icaresi Başkadınefendi ile birlikte diğer bazı harem kadınlarına teslim edilmiştir. Yine H.17 Rebiülevvel 1255/31 Mayıs 1839 tarihli bir belgede Başkadınefendi'ye ait bir eshâm kaydına ait dökümler görülmektedir. Toplamda 7.000 guruş tutarındaki eshâm, "Midilli Nezâreti mukataası fâizinden 5000, İmir cizyesi eshâmı fâizinden 500, Siroz cizyesi eshâmı fâizinden 1500 guruş" gibi kalemlere ayrılmaktadır. ${ }^{18}$

Hazîne-i Hassa tarafından şahsı için sahilhâne satın alınarak tefrîş ettirilmesi ve döşemelerinin yenilenmesine rağmen Hâce Nevfidan Başkadınefendi burada fazla yaşayamamış ve bir sene sonra vefat etmiştir. Techîz ve tekfîni esnasında ortaya çıkan masraflar yine Hazînei Hassa tarafından karşılanmışırı. Topkapı Sarayı Arşivi'nde yer alan bir Enderûn Hazînesi Harc-ı Hassa Defteri'nde bu masrafların kalemleriyle karşılaşılmaktadır. Deftere göre H.15. Rebîülâhir 1272/M.25 Aralık 1855 günü vefat eden Başkadınefendi'nin techîz ve tekfîninde hazır bulunan selatîn camileri şeyhlerine 1000, imamlarına 750 guruş verilmişti. Cenazede hazır bulunan diğer kişilerden Ayasofya şeyhine 500, Büyük Ağa imamına 120, türbedârlara ise 200 guruş verilmişti. Ayrıca taşçı, hamal, hassa müezzîni gibi birtakım kişilerin yanı sıra Bâb-ı Hümâyûn ve Topkapı Sarayı Odun Kapısı hademelerinden üç kişiye 250 guruş, Ebnîyei Hassa Müdîri hademelerine 200, Hazine-i Hümâyun Vekîli Ağa'nın hademelerine 150 guruş tutarında paralar verilmişti. ${ }^{19}$

17 BOA.TS.MA.e...1114/28. Terzi'nin verdiği listede Sultan II. Mahmûd'un eşlerinin Kasımîyeleri 3.000 guruş olarak görünmektedir. Bir sonraki tahsisât olan Muharremiye ise 5.000 guruştur. Terzi, a.g.e., s.46.

18 TS.MA.d...5102-1.

19 BOA.TS.MA.d...521/10.

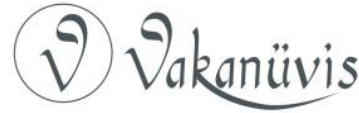


Hace Nevfidan Başkadın Efendi'nin techîz ve tekfîninde yapılan önemli harcamalardan birisi padişahın gönderdiği ihsândır. Sultan Abdülmecîd, vefat dolayısıyla Beylerbeyi semtinin fakir ve gariplerine dağıtılmak üzere 1.000 guruş bağışlamıştır. Diğer masraflar arasında Sertürbedâr-ı Hassa Ahmed Efendi yediyle harcanan 200 guruş, Evkâf-ı Hümâyûn Nâzırı tarafından Başkadınefendi'nin merkadı üzerine örtülmek üzere teslim edilen 2.000 guruş değerinde sekiz adet "fermâyiş şal"ın bedeli gibi kalemler göze çarpmaktadır. Bu kalemlerin yanı sıra defterde bazı başka meblağlarla da karşılaşılmaktadır. Nitekim Hazine Vekîli Ağa tarafından Harem-i Hümâyûn'a 10.000 guruş tutarında paranın teslim edildiği belirtilmektedir. Bu meblağın mahiyeti tam olarak anlaşılamamakla birlikte Başkadınefendi'ye ait olması mümkündür. Yanı sıra cenaze masrafları arasında "ince dülbend, siyâh peştemâl çift, farsî ve asûd (asude)" gibi çeşitli birim ve değerdeki kumaş parçalarııın varlığına rastlanmaktadır. Bunlardan bazılarının yanında "mevcûd" kaydı bulunmaktadır. Söz konusu kumaş parçaları Başkadınefendi'nin sandukasına örtülmek üzere bağışlanmış veya alınmış olmalıdır. Nitekim "pul ve kılabdan işlemeli canfes parçası ile tefârik parçası" kayıtlarının yanında görülen "ez Harem-i Hümâyûn" ibaresi bu kumaşların Başkadınefendi sandukasına örtülmek üzere saraydan gönderildiğini akla gelmektedir. Bütün bu kalemlerle birlikte, Başkadınefendi'nin techîz ve tekfîni için toplamda 16.5321,5 guruş harcanmıştır. ${ }^{20}$

Başkadınefendi'den sonra kendisi için satın alınıp tefriş edilen sahilhâne boş kalmamıştır. Vefat sonrasında sahilhânenin eski serasker Rızâ Paşa'ya ihsan edilmesine, içine yapılan döşsemelerin bedeli olan 700 kiselik meblağın kendisinden alınması şartıyla karar verilmiştir. ${ }^{21}$ Eski serasker Rızâ Paşa'ya yapılan bu ihsan arşiv belgelerinin yanı sıra dönemin devlet adamlarından Abdülhamîd Ferîd Paşa'nın günlüğünde karşımıza çıkmaktadır. Sadaret Mektûbî Kalemi'nde başladığı memurluk kariyerinde müsteşarlık, Meclis-i Vâlâ azalığı, mahkeme reisliği ve nazırlık gibi görevlerde bulunan Abdülhamîd Ferid Paşa günlüğündeki H.18 Rebiülâhir 1272/M.28 Aralık 1855 tarihli notlarında

\footnotetext{
20 BOA.TS.MA.d...521/10.

${ }^{21}$ BOA.TS.MA.e...608/28,612/31; İsmail Hakkı Uzunçarşılı, “Abdülhamid Ferid Paşa’nın Ruznâmesinden" Belleten, XXVII, S.106, 1963, s.262.
}

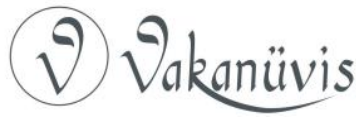


"Beylerbeyi'nde Nafîz Paşa merhûmun mübâyaa olunan sahilhânesinde mukîme Hâcce Başkadın Efendi vefât etmiş ve naâşı Bahçekapısına çıkarılarak cennetmekân türbesine defnolunmuşdur" bilgisini verdikten sonra, Başkadınefendi'nin Âdile Sultan'ın üvey annesi olduğunu, beraberce saraydan çıktıklarını, bir müddet beraber yaşadıklarını, daha sonra Başkadınefendi'nin sultandan ayrıldığından bahsetmektedir. Abdülhamîd Ferîd Paşa ertesi güne (19 Rebiülâhir) ait notlarında sahilhânenin padişah tarafından eski serasker Rıza Paşa'ya ihsan edildiğini belirtmektedir. ${ }^{22}$

Yapılan bu ihsanla birlikte Rızâ Paşa'nın Başkadınefendi'den kendisine geçen sahilhânede ikâmet etmediği anlaşılmaktadır. Haluk Y. Şehsuvaroğlu, 1950'li yıllarda Akşam Gazetesi'nde yayınlanan Tarihten Sayfalar adlı yazı dizisinde Vaniköy semtinde iskeleden Kuleli tarafına doğru olan Sırkâtibi Mustafa Paşa'ya ait bir büyük yalı ile yanında bulunan başka bir yalının serasker Rıza Paşa tarafından satın alındığını, yıktırılarak yerlerine daha büyük bir sahilhâne yaptırıldığını belirtmektedir. ${ }^{23}$ Söz konusu yalılardan ismi verilmeyen ikincisinin Başkadınefendi'nin vefatından önce ikâmet ettiği sahilhâne olması mümkündür. Şehsuvaroğlu'nun verdiği bilgi Rızâ Paşa'nın iç döşemelerin masrafı olan 700 kiseyi hazineye ödemesi karşılığı sahilhânenin kendisine verilmesi şartı ile uyuşmaktadır. Ancak bu hususta kesin bir şey söylemek zordur.

XVII. yüzyıla ait muhallefât defterlerindeki detaylara göre, Osmanlı konutlarında köşk, kasır, cihannüma, divanhane, mâbeyn odası gibi ana bölümler, bahçede bağımsız olarak bulunabilen mekanlar, baş oda, misafir odası, hazine odası, taş oda, yaldızlı oda, çinili oda, kâşili oda, kış odası, yaz odası şeklinde konut sahibinin statüsüne işaret eden oda ve bölümler bulunmaktaydı. Bunlarla birlikte, Osmanlı konutlarında pek çok isimsiz odanın yanı sıra özel işlevlere yönelik kahve odası, mutfak, kiler, hamam camekanı, abdesthane, çamaşırhane ve mahzenler üst sınıf konutlarında yer almaktaydı. Bu kısımların yer aldığı konut tipleri

\footnotetext{
22 Uzunçarşılı, a.g.m., s.264

23 TT. 501451- Haluk Y. Şehsuvaroğlu "Tarihten Sayfalar" Akşam Gazetesi, 1949; Şehsuvaroğlu ayrıca Beylerbeyi semtinde Beylerbeyi Cami'nden başlayarak Çengelköye kadar olan sahil kısmında birçok ileri gelen kişiye ait yalıların mevcut olduğundan bahsetmektedir. Şehsüvaroğlu, Boğaziçi'ne Dair, s.265 vd.
}

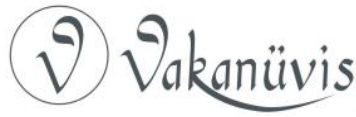


arasında yalılar da bulunmaktaydı. Su kenarında inşa edilen konutlar olan yalılar veya sahilhâneler genelde harem ve hariciye, yani iç ve dış bölümlerden oluşan 3 katlı yapılar olmakla birlikte 2 katlı olanlara da rastlanmaktadır. ${ }^{24}$

Başkadınefendi'ye Hazine-i Hassa tarafından satın alınarak tahsis edilen sahîlhâneyi oluşturan bölümler hakkında H.1270/ M.1854 tarihinde yapılan mefrûşâtı içeren defter vasıtasıyla bilgi sahibi olunabilmektedir. Deftere göre sahilhâne alt ve üst kat olmak üzere iki kattan oluşmakla birlikte bir de kayıkhânesi mevcuttu. Sahilhâne harem, selamlık, koltuk odası, kara tarafında bahçeye nazır sarı boyalı mâbeyn odası, uzun sofa, divanhâneler, harem içinde büyük divânhâne, üst kat selamlık ve alt kat selamlık, alt kat selamlıktaki odalar, yatak odası, yatak odasına giden sofa (yol), sahilhâne kapısının üzerindeki köşk, muhtemelen hizmetçilerin ve diğer personelin yaşadığı koğuş adlı kısım, en altta kayıkhâne, hamam, soğuk camekân, hamama giden pencereli koridor (yol) gibi kısımlardan oluşuyordu. ${ }^{25}$

Bu kısımlarla birlikte Mefruşât Defterinde sahilhânede aynı zamanda başka odaların da bulunduğu görülmektedir. Bu odalar Başkadınefendi'nin muhtemelen misafirlerini ağırladığı üst kattaki selamlığın karşısındaki nohudî boyalı oda, kara tarafında bahçeye nazır yeşil boyalı oda, haremin başladığı mâbeyn odası, bitişiğindeki sarı tavanlı oda, uzun sofada deniz tarafında beyaz oda, haremde büyük divânhâne bitişiğinde kurşunî döşeme kaplı oda, kara tarafında nohudî boyalı bir oda, bahçeye nazır kurşunî boyalı bir oda, hamama giden koridorun üstünde iki tarafı döşemeli odalar, alt katta selamlık odaları, soğuk camekân üzerinde odalar, alt katta yeşil boyalı bir oda, kurşunî boyalı bir oda, penbe oda ve gümüş oda olarak nitelendirilen diğer odalardı. ${ }^{26}$

\footnotetext{
${ }^{24}$ Pınar Yavuztürk Özyalvaç, "18.Yüzyıl Osmanlı Konutlarında Lüks ve Konfor Şartlarının Muhallefât Defterlerine Göre Değerlendirilmesi" Sigma Journal of Engineering an Natural Sciences, 6/1, 2015, s.93, 97.

25 TS.MA.d...7916/1-9

26 TS.MA.d...7916/1-9
}

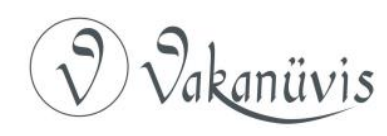




\section{Hâce Nevfidan Başkadınefendi ve Hayır Faaliyetleri}

Yukarıda vurgulandığı gibi hanedân arasında saygı gören ve itibar sahibi olan Hâce Nevfidan Başkadınefendi'nin çoğu hanedân mensubunun fırsatını bulamadığı hâc ibadetini yerine getirmesi dindarlığının bariz bir kanıtıdır. Bir padişah eşi olması sebebiyle kendisine tahsis edilmiş gelirlerin bir kısmını hayır faaliyetlerine ayırması ise hayırsever yönünü ortaya koymaktadır. Maddi imkânları elverdiği surette çeşitli eserler meydana getiren Başkadınefendi'nin bu faaliyetleri yakınlarını ve hayatının bir kısmını geçirdiği sarayı da kapsamaktadır. Örneğin, H.1264/M.1848 tarihli bir belgeye göre, kendisine tahsis edilen eshâmdan elde ettiği 1000 guruşu manevî kızı Âdile Sultan'ın azatlı cariyelerinden birisine tahsis etmiştir. ${ }^{27}$ Ömrünün önemli bir bölümünü geçirdiği Topkapı Sarayı için ise bazı vakfiyeler düzenlemiştir. Bu vakfiyeleri içeren kitabelerden birisi sarayın Araba Kapısı'nın yanındaki duvara yerleştirilmiş olup, Sultan II. Mahmud'un vefat ettiği H.1255/M.1839 tarihine aittir. Kitabede Başkadınefendi'nin Teberdarlar Koğuşu'na (Zülüflü Baltacılar Ocağı) beş kese para vakfettiğini, bu paranın koğuş için hazırlanacak aşurenin masraflarına eklenmesi belirtilmektedir. Başkadınefendi'nin saray duvarlarına yerleştirilen ikinci vakfiye kitabesi ise H.1266/M.1850-51 tarihli olmakla birlikte, H.1299/M.1880-81 tarihlerinde tamir edildiği ifadesi mevcuttur. Ancak hangi amaca tahsis edildiği açıkça belirtilmemiştir. ${ }^{28}$

Hâce Nevfidan Başkadınefendi'nin gerçekleştirdiği hayır faaliyetlerinden birisi kutsal topraklara gönderilen surre alaylarına yaptığı katkıdır. Her yıl düzenli olarak kutsal topraklara gönderilen hediye, para, altın ve eşyaları ifade eden surrelerin kaynaklarından birisi Haremeyn vakıfları idi. Hanedân mensupları ve devlet ileri gelenlerine ait vakıf gelirlerinin bir kısmı Haremeyn'e ayrılmıştı. Ayrıca devlet hazinesinden, Hazîne-i Hassa'dan ve bireysel bağışlardan önemli miktarlarda gelir toplanırdı. Bu bağış̧̧lardan birisi olmak isteyen

27 BOA.TS.MA.e...1206/65. Başkadınefendi'nin sehminden bir kısmını Âdile Sultan'ın azatlı cariyelerinden birisine tahsis ettiği belgede sultanın validesi olduğu vurgulanmaktadır. BOA.A.MKT.155/15; Bu durum diğer arşiv belgelerinde de görülmektedir. Terzi, a.g.e., s.45.

28 İkinci kitabede Başkadınefendi'den "Ez-zahîrât esvât'üt-zehrât iffetlû ismetlû Nevfidan Hâcı Başkadınefendi hazretleri" olarak bahsedilmektedir. Uluçay, Padişahların Kadınları ve Kızları, s.184.

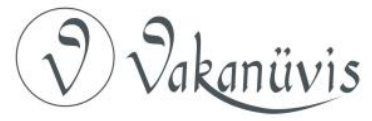


Başkadınefendi Sultan Abdülmecîd'den her sene surreye kendi ismiyle beş kese miktarı para eklenmesi için izin talebinde bulunmuştu. ${ }^{29} \mathrm{Bu}$ talep kabul edilmiş ve Başkadınefendi tarafından ayrılan belli bir miktarda para kutsal topraklara gönderilmişti. H.5 Cemâziyülâhir 1266/M.19 Mart 1850 tarihli bir belgeye göre Başkadınefendi uhdesindeki sehmlerden birisini Medîne-i Münevvere fukarasına gönderilmek üzere bağışlamıştı. Sehmin fâizinin hac mevsiminde Cidde hazinesinden verilmesi kararlaştırılmıştı. Haremeyn-i Şerifeyn Evkâf Defterleri'ndeki kayıtlara göre Başkadınefendi tarafından tahsis edilen para 2.500 guruş tutarındadır. Bu para intiyaç sahibi kişilere verilmek üzere Surre-i Hümâyûn ile birlikte yollanıyordu. Defterlerde söz konusu olan oran yukarıda bahsedilen beş keseye tekabül eden tutar olmalıdır. ${ }^{30}$

Başkadınefendi'nin hayır faaliyetleri arasında vefatından önce birtakım eserler yaptırarak bu eserlerin bakım ve masrafları için kurduğu vakıflar önemli bir yer teşkil etmektedir. Bu eserler sarnıç, çeşme, sıbyân mektebi ve cami gibi önemli halkın hizmetine tahsis edilmiş yapılardır. Kaynaklara göre Başkadınefendi Fatih Çarşamba'da bulunan Murad Molla Mesnevîhanesi'ne kitabesi bulunan bir sarnıç, Sarıgazi'de kitabesi bulunan bir çeşme yaptırmıştı. ${ }^{31}$ Yine Fatih Odun Kapısı semtinde bir mescîdi tamir ettirip masrafları için dükkân vakfetmiş, ayrıca Üsküdar Bülbülderesi Süleyman Ağa mahallesinde ahşap ve fevkani bir sıbyân mektebi yaptırmıştı. Söz konusu yapılardan cami ve sıbyân mektebi Başkadınefendi'nin katkılarından sonra ismiyle anılmaya başlanmıştı. ${ }^{32}$

\footnotetext{
${ }^{29}$ Ş.Tufan Buzpınar, "Surre” TDViA. C.37, (2009), s.567; Öztuna, a.g.e., s.254; Sakaoğlu, a.g.e., s.546; "Eğer izn-i hümâyûnunuz olur ise Medîne fukâraları için her sene sizin surre kalkdığı vakitte bu beş kîse akçe benim ismim ile gittiğin istiyorum..." Uluçay, Haremden Mektuplar, s.112

30BOA.A.MKT.MHM.20/40, "Atıfetlû Başkadınefendi'nni eshâm fâizinden Medîne-i Münevverede bâ'zı kesâna-2.500 guruş". BOA. EV.d...12420/10

${ }^{31}$ Başkadınefendi tarafından Sarıgazi'de bir çeşmenin yaptırıldığı bilgisine rağmen, kaynaklarda bu çeşme ve kitabesi hakkında herhangi bir bilgiye rastlanmamıştır. Bu bakımdan çeşmenin Sarıgazi' de bulunan Nakşidil Valide Sultan Çeşmesi ve Üçüncü Kadın Çeşmesi ile karıştırılmış olması imkân dahilindedir.

32 Mehmet Nermi Haskan, Yüzyıllar Boyunca Üsküdar, C.2, Üsküdar Araştırmaları Merkezi Yayınları, (2001), s.921; Ş. Pınar Yavuztürk, "Bir Müfettişin Defterinden Üsküdar Sıbyan Mektepleri", Uluslararası Üsküdar Sempozyumu-VI Bildiriler, C.II, Üsküdar Belediyesi Yayınları, (2007) s.557, 567; Mehmed Süreyya, a.g.e., s.32; Öztuna diğer
}

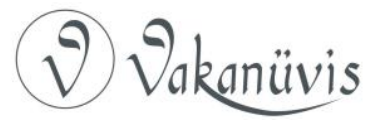


Başkadınefendi tarafından yenilettirilen söz konusu mescîd, Odun Kapısı semtinde bulunan Hâdice Hâtûn Camisi'dir. Hâdice Hâtûn Cami' mescîd iken camiye çevrilmiştir. Başkadınefendi ise cami hüviyeti kazanmış yapıyı yenilediği gibi ayrıca vakfiye tanzim etmiştir. Belgelerden anlaşıldığı kadarıyla Hâdice Hâtûn Cami' önceleri bir mescîd sıfatını taşımaktayken bazı hayırsever şahıslarca içine minber konularak cami hüviyeti kazandırılmıştır. Anca bir süre sonra yanmış, yangın sonrasında ise Başkadınefendi tarafından yeniden inşa ettirilmiş ve bazı masrafları için vakfiye tanzim edilmiştir. Vakfın idaresi ilerleyen tarihlerde Evkâf-ı Hümâyûn Nezâreti'ne geçince, vakıf mazbut kategorisine girmiştir. ${ }^{33}$

Başkadınefendi'nin Hâdice Hâtûn Cami için düzenlediği vakfiye H.1267/M.1850-1851 tarihlidir. Vakfiyesinde yeniden inşa ettirdiği cami için para ve gayrimenkul tahsis etmiş ve paradan hasıl olan nemadan camide hitâbet görevini üstlenenlere aylık 15 guruş vazife verilmesini şart koşmuştur. Vakfiyedeki gayrimenkul ise camiyi yeniletirken altına inşa ettirdiği dükkanlardır. Bu dükkanlardan birisi müzayede usulü ile H.6 Ramazan 1284/M.1 Ocak 1868 tarihinde aynı yılın Şa'ban ayı başından (Kasım 1867) H.1285 senesi Zilhicce ayı (Mart 1869) arasın on dokuz aylığına ayda 280 guruştan toplamda 5.320 guruşa Bârgîr Hamalları Kethüdâsı vekîli tarafından kiralanmıştı. ${ }^{34}$

Başkadınefendi'nin yaptırdığı tamir ve düzenlediği vakfiyesiyle birlikte cami yukarıda belirtildiği gibi ilerleyen tarihlerde "Nevfidan Kadın Cami'-i Şerîfi" olarak adlandırılmıştır. Fevkanî yani iki katı olan cami bir yangın daha geçirmiş, Başkadınefendi'nin vakfettiği ahşap dükkanlar cami ile birlikte yanmıştı. H.24 Zilhicce 1320/M.24 Mart 1903 tarihli bir belgeye göre, yangın sonrası yapılan keşif neticesinde yanan cami ve dükkanların yenilenmesi için 120.552 guruş, 50 santimlik masrafa ihtiyaç vardı. Cami ile birlikte yeniden inşa edilecek beş dükkândan üçü Evkaf Hazînesi, biri Hazîne-i Hassa, biri ise özel bir şahıs

kaynakların aksine mescidin Zindankapı'da olduğunu belirtmektedir. Öztuna, a.g.e., s.254.

${ }^{33}$ Vakfiyesinde Başkadınefendi'den "Sahîb'ül-hayrât ismetlû Nevfidan Kadınefendi bint Abdullah" olarak bahsedilmektedir. BOA.C.EV..537/27126; BOA. ŞD.161/7; BOA. EV.d...20650-3.

${ }^{34}$ Belgelerde vakıf olarak tahsis edilmiş olan dükkânda içki satılmayacağı, kumar oynatılmayacağı vb. hususlara değinilmiş̧ir. BOA. C.EV..537/27126; EV.d...20650-3.

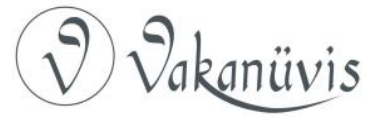


uhdesinde bulunacaktı. İnşa için gereken masraflara bir hayırsever tarafından 10.000 guruş iane yapılmıştı. ${ }^{35}$

Tahsin Öz, İstanbul camileri hakkında kaleme aldığı eserinde Odunkapısı Mescîdi, Nevfidan Kadın Cami' ve Çürükelma Cami'nin aynı yapı olduğunu, Nevfidan Kadın Cami'nin 1924 tarihinde yeniden ihyâ edildiğini, fevkanî ve ahşap bir yapıya sahip olan caminin metruk halde bulunduğunu belirtmektedir. Öz'ün verdiği bilgilerden anlaşıldığı kadarıyla, Başkadınefendi tarafından yeniden yaptırılan cami, Çürükelma Cami' ile karıştırılmaktadır. Bu iki eser birbirine yakın olmakla birlikte, Nevfidan Kadın Cami' Çürükelma Cami'nin kuzeydoğusunda bulunmaktadır. Öz'ün bahsettiği tarihte metruk halde bulunan cami ilerleyen tarihlerde ortadan kaldırılmıştır. Kararlaştırılan imar planı gereğince yapılan yol genişletme çalışmaları sırasında yıktırılmış, Bakanlar Kurulu'nun 1959 tarihli onayı ile yerinin belediyeye satılması kararlaştırılmıştır. ${ }^{36}$

Hâce Nevfidan Başkadınefendi'nin diğer bir önemli hayır eseri ise Üsküdar Bülbülderesi'nde Süleyman Ağa mahallesindeki sıbyân mektebidir. Mimarî olarak yenilettiği cami ile benzer şekilde ahşap ve fevkâni yapıda olan ve kendi adıyla (Nevfian Kadın Mektebi) anılan mektep, sadece kızlara eğitim vermekteydi. Arşiv belgelerinde Atlama Taşı ve Şeyh Cami civarında bulunduğu belirtilen mektep için Başkadınefendi vakfiyesinde mektebin altında bir dükkân inşa ettirerek icâresinden muallimenin maaşı olarak ayda 45 guruş verilmesini şart koşmuştu. Illerleyen tarihlerde dükkândan elde edilen icâre Maârif Nezâreti tarafından alındığından yeniden vakıflara ait olması için Evkaf ve Maârif nezâretleri arasında çeşitli yazışmalar yapılmıştı. ${ }^{37}$

Başkadınefendi'nin yaptırdığı sıbyan mektebi imparatorluğun son yıllarına kadar hizmet vermiş, cumhuriyetin ilk yıllarında ortadan kalkmıştır. R.12 Nisan 1327/M.21 Nisan 1911 tarihli bir belgede, Üsküdar Bülbülderesi'nde bulunan Tevfîkiyye Mektebi'nin muallimi vefat ettiğinden talebelerin eğitimi mümkün olmadığı için Nevfidan

\footnotetext{
35 BOA.ŞD. 161/7; Y..A...RES.119/91; BOA. BEO. 2084/156270.

36 BCA. Başbakanlık Kararlar Daire Başkanlığı, 154-68-3; Nurcan Sefer-Zeynep Ahunbay, "Eminönü'nün Haliç Kıyı Bölgesindeki Vakıf Kültür Mirası'nın 1920-2015 Arasında Geçirdiği Onarımlar ve Uğradığı Kayıplar, Restorasyon Yıllığı Dergisi, S.10, (2015), s.110. 37 BOA.MF.iBT.252/11, 295/80; Yavuztürk, a.g.m., s.557, 567.
}

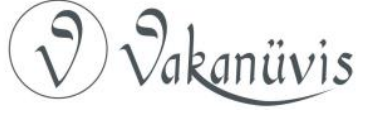


Kadın Mektebi'ne nakilleri ve erkek öğrenci varsa başka bir mektebe gönderilmelerinin kararlaştırıldığı belirtilmektedir. Ancak alınan bu karara rağmen, iki yıl sonra, M.27 Mayıs 1913 tarihinde yapılan bir teftişte mektebin boş olduğu ve eğitim verilmediği görülmektedir. Bu şekilde, 1924 tarihine kadar bakımlı bir halde bulunan mektep daha sonraları harap olarak cami gibi ortadan kalkmıştır. ${ }^{38}$

\section{Hâce Nevfidan Başkadınefendi'nin Muhallefâtı}

Vefat eden bir kişinin arkasında bıraktığı malların bütünü tereketerike veya muhallefât adı verilmekle birlikte, bu malların kayıtlarının tutulduğu defterlere Tereke veya Muhallefât Defterleri adı verilmektedir. ${ }^{39}$ Osmanlı sosyo-ekonomik ve kültürel yaşamı hakkında detaylı bilgiler içeren bu defterlere dayanarak başta devlet adamları olmak üzere ${ }^{40}$ resmi görevliler ve Osmanlı toplumunun çeşitli sınıflarına mensup şahıslar hakkında önemli araştırmalar kaleme alınmıştır. Söz konusu çalışmalar arasında kadınlara ait olan çalışmalar hatırı sayııı bir yer tutmaktadır. ${ }^{41}$

Osmanlı toplumunu oluşturan sınıflardan birisini olmaları hasebiyle, tereke veya muhallefât defterlerine dayanarak haklarında araştırmalar yapılanlar kişiler arasında saraylı kadınlar da bulunmaktadır. Ancak, içerdikleri önem itibarıyla Osmanlı devlet adamlarının muhallefâtlarıyla ilgili birçok araştırma yapılmış olmasına rağmen, toplum sathında seçkin sayılabilecek saray kadınlarının terekeleri daha az sayıda çalışmaya konu olmuştur. Bununla birlikte son zamanlarda bu husustaki inceleme ve araştırmalarda artış görülmektedir. ${ }^{42}$ Bu çalışmalarda valide sultan, sultan, hanım sultan, cariye, usta, kalfa, gibi çeşitli statülerdeki saray kadınlarının geride bıraktıkları eşya ve mallarının dökümlerini içeren defterler incelenip, elde edilen veriler analize tabi tutularak değerlendirilmekte, bu değerlendirme neticesinde söz konusu

\footnotetext{
${ }^{38}$ BOA. MF.IBT.295/80; Yavuztürk, a.g.m., s.567.

39 M.Zeki Pakalın, Osmanlı Tarih Deyimleri ve Terimleri Sözlüğü C.III, İstanbul, 1993, s.460, 564.

40 Yusuf Sağır, "Valide Turhan Sultan'ın Muhallefâtı" Çanakkale Araştırmaları Türk Yıllığı Dergisi, S.20, Çanakkale, (2016) s.266.

${ }^{41}$ Akademik düzeyde yapılan tereke veya muhallefât çalışmaları hakkında örnekler için, Fatih Bozkurt, "Osmanlı Dönemi Tereke Defterleri ve Tereke Çalışmaları" Türkiye Araştırmaları Literatür Dergisi, C.11, S.22, İstanbul, (2013), ss.193-229.

42 Sağır, a.g.m., s.266.
}

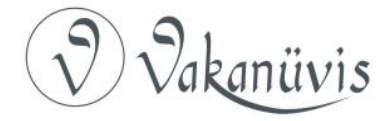


muhallefâtın ait olduğu dönem hakkında önemli bilgiler elde edilebilmektedir. ${ }^{43}$

Bazıları sarayda yaşarken, bazıları ise ayrıldıktan sonra vefat eden saraylılara ait muhallefât veya terekeleri içeren defterler Topkapı Sarayı Arşivi'nde muhafaza edilmektedir. Bu saraylı kadınlardan birisi de incelememizin konusu olan Hâce Nevfidan Başkadınefendi'dir. Kendisine tahsis edilen sahilhâne için yapılan yenilemeler ve cenaze masrafları gibi, Başkadınefendi'nin muhallefâtı da detaylarıyla kayıt altına alınmıştır. Bu kayıtlar Topkapı Sarayı Arşivi'nde bulunan ve "Müfredât Defteri" başlığını taşıyan iki defterde bulunmaktadır. Yaptığımız araştırmada bu iki defterden başka Başkadınefendi'ye ait bir Muhallefât Defteri'ne rastlanmamıştır. Her iki defter, ciltsiz ve ebrusuz olup birisi boş olmak üzere toplamda dört sayfadan ibarettir. Defterlerden ilki, H.11 Cemâziyülevvel 1272/M.9 Ocak 1856 tarihiyle Başkadınefendi'nin vefatından on üç ay sonrasına ait olup, "Cennetmekân Hâcı Baş kadın hazretlerinin eşyâsından ifrâz olunub Hazîne-i Hümâyûnda muvakkaten muhâfaza olunan" başlığı ile kayda geçirilmiştir. Tespit ettiğimiz ikinci defterde ise herhangi bir tarih bulunmamakla birlikte "Cennetmekân Hâce Baş Kadın hazretlerinin dâirelerinde mevcûd bulunan elbise ve sâir eşyânın defteridir" başlı̆̆ı görülmektedir. Bu başlıklardan anlaşıldığı kadarıyla birinci defterdeki eşyalar sahilhâneden alınarak satılana kadar Hazine-i Hümâyun'a muhafaza edilmiştir. İkinci defterdeki eşyalar için ise net bir çıkarım

\footnotetext{
${ }^{43}$ Saraylı kadınlara konu edinen bazı muhallefât çalışmaları için bkz. Sağır, a.g.m.; Özer Küpeli, "Kösem Sultan'a Ait Bir Muhallefât Kaydı" Cihannüma Tarih ve Coğrafya Araştırmaları Dergisi, S.I/2, (2015), ss.131-143; İsmet Sarıbal, "Pertevniyal Valide Sultan'ın El Konulan Hazinesine Dair Tutulan Bir Defterin Analizi" Cihannüma Tarih ve Coğrafya Araştırmaları Dergisi, S.IV/1, (2018), ss.131-154; Rahmi Tekin, "Osmanlı'da Üç Hanım Sultanın Ziynet Eşyası" Bingöl Üniversitesi Sosyal Bilimler Dergisi” C.8, S.15, (2018), ss.297-316; Ş. Pınar Yavuztürk Özyalvaç, "Bir Osmanlı Cariyesinin Şahsi Eşyaları: "Sarayî Emetullah Hatun" Kültür, S.16, (2016), ss.28-31. Bu çalışmalarla birlikte bazı araştırmalarda da saraylı kadınlara ait muhallefât kayıtlarına yer verilmiştir: Bkz. Betül İpşirli Argıt, Gülnuş Emetullah Valide Sultan, (1640-1715), Kitap Yayınevi, İstanbul, 2014, s.211-236; Ali Akyıldız, Mümin ve Müsrif Bir Padişah Kızı Refia Sultan, Tarih Vakfı Yurt Yayınları, İstanbul, 1998, s.92 vd. Söz konusu örneklerle birlikte konu hakkında çok sayıda makale, kitap, tez ve bildiri gibi çalışmalar mevcuttur.
}

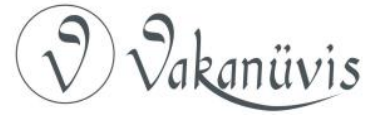


yapmak zordur. Bu eşyalar da sonradan Hazîne-i Hümâyûn'a getirilmiş olabilir. ${ }^{44}$

Bu defterlerle birlikte, Sultan Abdülmecîd'in üçüncü ikbali olan Ceylanyâr Hanımefendi'nin muhallefâtını içeren başka bir defterde, kendisine ait iki eşyaya ait kayıtlar bulunmaktadır. H.16 Cemaziyülevvel 1271/M.4 Şubat 1855 tarihli bu defterin 4. sayfasında "Cennetmekân Hâcı Başkadın Hanım Efendi hazretlerinin muhallefâtı defteri" ibaresiyle iki eşyasının kaydına rastlanmaktadır. illk eşya 14.120 guruş tutarındaki "Vaşak kürk ve Moskov perdesi" olup altındaki şerhe göre Başteberdâra satılmıştır. İkinci eşya ise 1.901 guruş tutarındaki "Beyaz fermâyîş şâlï" olup yine altındaki şerhe göre İkinci Efendi'ye satılmıştır. ${ }^{45}$

İki muhallefât defterine göre, Hâce Nevfidan Başkadınefendi'nin geride bıraktığı malları giysiler, mücevher ve takılar, oturduğu sahilhâneye ait döşemeler, sahilhânede çeşitli ihtiyaçlar için kullanılan eşyalar, gündelik hayatta kullanılanlarla, hamam ve mutfakta kullanılan araç, gereç ve eşyalardan ibarettir. Bunlarla birlikte muhallefâtta atların, bir dolap beygirinin, bir buzağı ve bir miktar yakacağın mevcudiyeti ile karşılaşılmaktadır. Yapılan sayım neticesinde, sahilhânenin şitâiyye (kışlık) sayfiyye (yazlık) döşemeleri ile limonluk, matbah takımları ve diğer eşyalardan ibaret olduğu belirlenen muhallefât toplamda 3 yük 50.000 (350.000) guruşa Hazîne-i Hümâyun tarafından satılmıştır. ${ }^{46}$

Başkadınefendi muhallefâtındaki detaylara geldiğimizde ilk sırada mücevherlerden bahsetmek yerinde olacaktır. Mücevherlerin aşağıda görüleceği üzere giysiler ve değerli eşyalar gibi fazla sayıda olmadığı söylenebilir. Mücevherlerden ve mücevher içeren değerli eşyalardan yüksek değere sahip olanların dökümünün yapıldığı kısımda "Baş Musahîb Râsim Ağa marîfetiyle takdîm-i hâk-i pây-i şâhâne kılınan" başlı̆ı̆ görülmektedir. Böylece padişaha takdim edildikleri anlaşılmaktadır. Bu mücevher ve değerli eşyalar: "Ortaları penbe kübeli gül resminde iğneler, pırlanta yüzük, altun kutı, el resminde altundan

\footnotetext{
${ }^{44}$ BOA. TS.MA.d...8124, 8127.

45 BOA.TS.MA.d...426-4; Bu iki kayıtla birlikte Bu kayıtlarla birlikte, yine ikinci ikbâl Ceylanyâr Hanmefendi'ye ait ve aynı tarihli başka bir muhallefât defterinde "Hâce Başkadınefendi'nin şalı sehven buraya girmiş olduğundan tenzil" ifadesi ile karşılaşılmaktadır. BOA.TS.MA.d...423/5 46 BOA.TS.MA.d...8124, 8127; BOA.TS.MA.e...608/28.
}

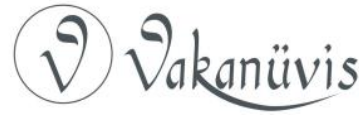


mercan sablı muhâfaza derûnunda bir alet, nişân yerleri incüli altun şemsiyeli ağır tesbih, gümüş kamçılı mercan teşbih, sarı ma'den üstüne laciverd minekârî incüli dürbîn"dir. Söz konusu mücevherler ve eşyaların sultan tarafından saray kadınları ve harem personeline ihsân edilmiş olmaları kuvvetle muhtemeldir. Bu kısımda bulunmamakla birlikte Başkadınefendi'nin değerli eşyaları arasında ayrıca iki aynaya rastlanmaktadır. Aynalardan ilki "sim kablı ayîne" olup yanına "an derûn-ı muhâfaza" ibaresi konulmuştur. Diğer gümüş ayna "sim sablı gümüş ayine" olarak kayıtlıdır. Ayrıca "altun yaldızlı sim zerdeste" ile elmas kesim aleti olan üç "elmastraş" ın varlığına rastlanmaktadır. ${ }^{47}$

Başkadınefendi'nin muhallefâtını oluşturan mal varlığı arasında ikinci sırada elbiselerini koymak mümkündür. Bu hususta ilk dikkati çeken nokta, deftere kaydedilmiş giysilerin azlığıdır. Başkadınefendi'nin elbiselerinin "Kılabdanlı al ihram, al şâlâkî üstüne beyaz sırma işlemeli vaşak kürk, tirşe ile kırmızı suyalı derununda vaşak kablı kürk, şâlâkî kaplu kayum (kakum?) kürk, sarı kablı merinoz samur kürk, leylâkî şâlâkî üstüne etrafı sarı sırma işlemeli kürk kabı, kılabdan işlemeli mücedded abdest sevbleri ve Düz rehavi(havî?) ${ }^{48}$ Burusa sevbleri, mor kemhâ bir takım çuka urba, yeni çuka urba" olduğu görülmektedir. Bunlardan "Burusa sevbleri" 24 adet, "kılabdan işlemeli abdest sevbleri" ise 9 adet olarak kaydedilmiştir. ${ }^{49}$

Başkadınefendi'nin muhallefâtında elbiselerle birlikte, bir takım kumaş ve dokuma mamulleri mevcuttur. Bunların muhallefâtın önemli bir kısmını oluşturdukları görülmektedir. Söz konusu kumaş ve dokuma mamulleri, sahilhânedeki eşyalara örtüldükleri ve çeşitli yerlerde kullanıldıkları gibi muhtemelen elbise yapımı vs. için alındıkları anlaşılmaktadır. Muhallefâtta: "Hindî telli sivaî (1 tob), çetarî (2 tob), abanî (7'şerden 14 tob); Mütenevvî boğça: Sağîr ve kebîr üstüfe (7 aded)-tomar güvezli maîli (4 aded), üstüfe ağır boğça, ağır işlemeli şâlâkî boğça, ipek kemhâ boğça, ağır sırma işlemeli havî, Burusakârî yatak bağı (5 aded), Burusa'nın canfesi üzerine yatak bağı (5 dane), 1 tob ince kılabdanlı kuşak (10 adet), yün işlemeli kahve örtüsü, Hind kumaşı (3 tob), beyaz armalı şâlî (3,5 zirâ' 1 parça), marpuçlu şâlî (4 zirâ' 1 parça),

\footnotetext{
${ }^{47}$ BOA.TS.MA.d...8124-1, 8127-2.

48 (رحاوى دوز) BOA. TS.MA.d...8127-1.

49 BOA.TS.MA.d...8124-1, 8127-1/2.
}

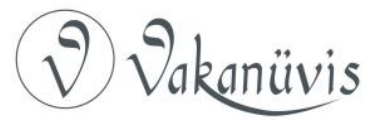


beyaz armalı şalî (2,5 zirâ' 1 parça), zâr" gibi dokuma mamulleri ve kumaşlar çeşitli birim, ölçü ve oranlarla kaydedilmiştir. ${ }^{50}$

Muhallefâttaki dokuma mamulleri yukarıdakilerle sınırlı değildir. Defterlerde görülen benzer eşyalardan bazılarının "takım" olarak kaydedildikleri görülmektedir. Bunlardan iki adet "güvez ve mor kemhâdan iki kat kayık takımı"nın Başkadınefendi'nin kayıkla yaptığı seyahatler esnasında kullanıldıkları açıktır. Takım olarak kaydedilen diğer eşyalar ise günlük hayatta kullanılmaktadır. Bunlar: "ipekli turuncu kemhâdan yasdıkları ve erkân takımı, yeşil atlas üzerine kılabdan suyalı ağır büyük erkân takımı, çiçekli Farskârî iki dane erkân takımı, marinoz üzerine kasnak işi işlemeli tandır takımı, çiçekli marinozdan tandır takımı, al marinoz üzerine çiçekli tandır takımı, sarı harsdan (harç?) yer takımı, etrafı çuka maûn üzerine yaldızı yatak takımı, Çaşnigîr takımı ağır havî ${ }^{11}$ tırtılı sofra (9 aded), Çaşnigîr takımı kılabdan ipek işleme havi (14 aded)". ${ }^{52}$ Her ne kadar takım olarak nitelendirilmeseler de "Yalının yazlık döşemeleri" ibaresiyle defterlere kaydedilen döşemeleri aynı gruba dahil edebiliriz. 23 boğça halinde toplanan bu döşemeler daha önce bahsedildiği üzere sahilhânenin Hazine-i Hassa tarafından yenilenen döşemeleridir. ${ }^{53}$

Sahilhânede günlük yaşamda kullanılan benzer nitelikli, yani dokuma mamulü eşyalar arasında bulunan seccâdeler sayı ve çeşitleriyle dikkat çekmektedir. Başkadınefendi'nin sahip olduğu seccâdelerin: “Canfes üzerine beyaz sırma işleme seccade (maa-minder), sûzenî işlemeli al marinoz seccade, yazma seccâde (2 aded), kadife ipekli işleme çuka seccâde, sarı ipek işleme canfes seccâde, kahverengi atlas üzerine sırma işlemeli ve kılabdan saçaklı minderiyle seccâde, siyah merinoz üzerine kılabdan işleme seccâde, kılabdan işlemeli Burusakârî seccâde, kahverenkli merinoz üzerine kadife sûzenî seccâde, merinoz ve şâlâkî üzerine işleme seccade (4 aded)" olduğu görülmektedir. ${ }^{54}$

\footnotetext{
50 BOA.TS.MA.d...8127-1/2.

حاوى

52 BOA.TS.MA.d...8127-1/2.

53 BOA.TS.MA.d...8127-1; "Başkadın Efendi hazretlerinin sahilhânesinin dahîlen ve harîcen sayfiyye mefrûşâtı müceddeden ferş" H. 3 Safer 1271/ M. 26 Ekim 1854; BOA: TS.MA.e...603-76.

54 BOA.TS.MA.d...8124-1, 8127/1.
}

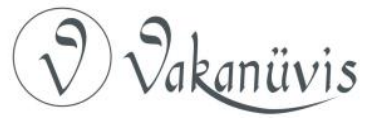


Muhallefâtda mevcut olan dokuma mamulü eşyalar arasında ayrıca yorgan, yasdık, minder, erkân, çarşaf, şilte vb. gibi oturma, dinlenme ve istirahat esnasında kullanılanlara rastlanmaktadır. Bu eşyalar: "Kılabdan suyalı yeşil zeminli erkân, rengâmîz yazmalı yasdık (20 aded), kılabdan işlemeli yasdıklar (3 aded), güvezli kemhâdan erkân minderi ve yasdığı, güvez zemîn üzerine yazma minder (3 aded), küçük erkân minderleri (5 aded), çarşeb, (3 aded), ipekli çarşeb (3 aded), kılabdan ve ipek ile işlemeli yorgan (3 aded), kasnak işi işlemeli yorgan (2 aded), birincek (bürümcük) ve yazma yorgan (17 aded), tukma (tıkma) ve basma olarak şilteler (12 aded),canfes şilte, birencik (bürümcük) şilte" dir. ${ }^{55}$ Bunların yanı sıra: "Beyaz sırma işlemeli abdest havlusu: (2 aded), ağır sırmalı abdest havlusu (4 aded), ayak havlusu? (2 aded), yün işlemeli kahve örtüsü (2 aded), maîli şâlâkî üzerine pul işlemeli kahve örtüsü, gümüş şâlâkî üzerine pul işleme sofra, Mardinkârî futa kılabdan ${ }^{56}$ Bursakârî yatak bağı (5 aded), Burusa canfesi üzerine yatak bağı (5 aded), yatak bağı (2 aded), kılabdanlı sofra (2 aded), ağır sırma işlemeli havî, peşkîr (2 aded), kılabdan abdest futası (12 aded), futa peşkîr (2 aded), ipek abdest futası (5 aded), çuka perdeler (2 aded)" gibi başka eşyalarla karşılaşılmaktadır. ${ }^{57}$

Başkadınefendi muhallefâtında gündelik hayatta kullanılan diğer eşyalar arasında aydınlatma, ısınma, muhâfaza vb. ihtiyaçlar kapsamında kullanılan ve gümüş, maûn, pirinç, ahşap vb. gibi değerli maden ve maddelerden yapılan eşyalar mevcuttur. Ayrıca bazılarının üzerinde yine dokuma mamulü kumaşlar kullanıldığı görülmektedir. Bu eşyalar şamdan, gülâbdan, buhûrdân, mangal, tepsi, çekmece, sandık, sofra, anbar, çekmece, rahle saat vb. eşyalardır. Defterlere göre şamdanlar: "Yaldızlı kebîr ma'den şamdan (2 aded)- parça (2 aded), sim ufak şamdan (2 aded) ve tebsi, beyaz ma'den kebîr şamdan (2 aded), ma'den şamdan (6 aded), ma'den tebsi (2 aded), üzerinde iki fanuslu müressem şamdan maa-makras (1 aded), sarı leğen pirinç şamdan parça (2 aded); mangal: "ayaklı pirinç mangal maa-kapak"; gülâbdân ve buhûrdânlıklar:"muhafaza derûnunda sim gülâbdân maa-buhûrdân (hafif ve 1 aded), yeni gümüş iki buhûrdânlık ve iki gülâbdânlık (4 aded);

\footnotetext{
55 BOA.TS.MA.d...8124-1, 8127/1.

56 Defterde söz konusu Mardinkârî futa ibaresinden sonra $(\boldsymbol{l})$ kelimesi gelmekle birlikte, bu kelimenin yarım bırakıldığı, doğrusunun kılabdan olduğu düşünülmüştür. 57 BOA.TS.MA.d...8124-1, 8127/1/2.
}

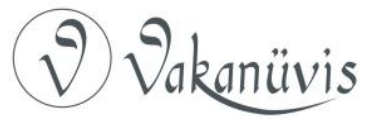


sofralar: "ma'den sofra (2 aded)" sandık çekmece, ve rahleler: "sim sandık, mum anbarı, güvez kadife üzerine sim paftalı sağir çekmece, maûn kablu rahle ve kadife kablu çekmece (2 aded)"; saatler: "çalgılı saat (3 aded), olarak kayıtlıdır. ${ }^{58}$

Osmanlı konutlarında iç mekanlardan birisi olan sofalarda genellikle mefrûşât ve mobilyalar mevcut olup, bazen odaların arasındaki küçük alanlar minder yastık ve mak'ad gibi eşyalarla değerlendirilmekteydi. Bununla birlikte sofaların bazen cariye veya misafirlerin yatak takımlarının, elbiselerin, fincan tabak gibi küçük mutfak eşyalarının tahta anbarlarda muhafaza edildiği alanlar oldukları görülmektedir. Sofalarda bazen hane sahiplerinin biraraya geldiklerinde oturdukları burada kullanılan yer yaygıları, iskemle, mangal ayna, çalar saat gibi eşyalardan anlaşılmaktadır. Ayrıca sofalarda kullanılan mefruşatlar daha ziyade lüks kumaşlar arasından tercih edilmektedir. ${ }^{59} \mathrm{Bu}$ bakımdan Başkadınefendi muhallefâtında yer alan benzer nitelikli eşyaların da aynı amaçlar için kullanıldıklarını söylememiz mümkündür.

Osmanlı konutlarındaki hizmet mekanlarından birisi olan mutfaklar, sebze, tahıl veya çöp giriş çıkışının görülmemesi, koku gibi olumsuz unsurlara maruz kalınmaması amacıyla daha çok giriş katlarında, diğer servis mekanlarının yakınında veya bahçelerin uzak bir köşesinde yer almışlardır. Burası zarif yemek takımlarının değil, kalabalık bir nüfusa yemek pişirmek üzere kullanılan kazan, tencere, lenger, tava gibi pişirme kapları, süzgeç, kepçe, kevgir gibi araç-gereçlerin bulunduğu mekanlar olmuştur. ${ }^{60}$ Muhallefât defterlerinde yukarıda bahsedilen kalemlerden sonra, mutfak ve sofrada kullanılanlarla, hamam ve temizlik ihtiyacının karşılanmasında kullanılan eşyalar ağırlıklı grubu teşkil etmektedir. Başkadınefendi'ye ait sahilhânenin mutfağında kullanılan eşyalardan bazıları defterlerde "Matbah Takımı"61 başlığıyla kaydedilmiştir. Bu eşyalar: "Kebîr ve sağîr sahanlar (45 aded), kebîr ve sağîr kuşhâneler (41 aded), kebîr ve sağîr bakır tebsi ve iki kuşhâne (17

\footnotetext{
58 BOA.TS.MA.d...8124-1, 8127/2.

59 XVIII. yüzyıla ait muhallefât defterlerine göre genellikle kilerlere konulan bazı sandıklarda aydınlatma eşyaları, Viyana işi tabak ve bardak, İngiliz yemek takımları ve yatak takımları gibi eşyaların muhafaza amaçlı konulduğu görülmektedir. Yavuztürk, a.g.m., s.95-96.

60 Yavuztürk, a.g.m., s.96

61 BOA.TS.MA.d...8127/1/2.
}

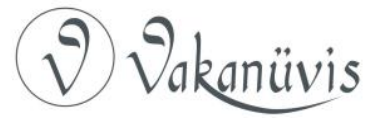


aded), kebîr bakır güğüm ve sağîr gügüm (6 aded), hurde bakır tebsi ve kadaif tebsisi (6 aded), nuhâs kebîr kazgan"dır. Bununla birlikte söz konusu başlık altına kaydedilen eşyaların bunlarla sınırlı olmayıp başlığın altında hamamda kullanılan eşyalara da yer verilmesi dikkat çekmektedir. Bu bakımdan sahilhâne mutfağının büyük bir ihtimalle sahilhânenin alt katındaki hamama yakın olduğu anlaşılmaktadır.

Muhallefâtta aynı kategoride değerlendirilebilecek kalemlerden birisi de çeşitli hizmetlerde kullanılan bazı hayvanlarla, yakacak maddelerdir. Yakacaklar defterde "hatab ve kömür haylice mevcuddur" olarak belirtilmiştir. Hayvanlar ise "Altı re's esb ve bir re's buzağı, bir re's dolâb bârgiri" olarak kayıtlıdır. Bu hayvanlardan atların taşıma ve diğer hizmetlerde kullanıldıkları açıktır. Dolâb bârgîri bahçede su kuyusunun varlığını göstermektedir. Buzağı ise muhtemelen ileride süt ve benzeri ürünleri tedarik etmek için alınmıştır. ${ }^{62}$ Bahçede aynı zamanda Osmanlı halkının çoğunluğu tarafından tercih edilen bazı sebzelerin yetiştirildiği bostan ile çeşitli meyve ağaçlarının ve çiçeklerin varlığını düşünebiliriz. ${ }^{63}$

Başkadınefendi'nin sahip olduğu eşyalar Saksonya menşeli olanlar dikkat çekmekte olup, bu ürünler mutfak eşyaları arasında dikkat çekici bir oran teşkil etmektedir. Bilindiği gibi XIX. yüzyılda Avrupa porselenlerinden özellikle Dresden üretimi olanlar Osmanlı sarayında yaygın olarak tercih ediliyordu. Bu porselenler lüks değil günlük eşya olarak değerlendiriliyor ve kullanım alanına göre isimlendiriliyorlardı. ${ }^{64}$ Eski bir saraylı olan Başkadınefendi de Saksonya üretimi eşyalara sahipti. Defterlerde "Saksonya ağır taslı ibrik (2 aded), muhâfaza derûnunda Saksonya desti, muhâfaza derûnunda Saksonya sürahi, üzerleri kabarmalı Saksonya üsküreler, sarı Saksonya olarak su maşrabası, Saksonyadan bir çift su testi, düz Saksonya kâseler (30 aded), büyük Saksonya kâse, Lahana resminde Saksonya kâse (3 aded), Saksonya olarak hoşab kâsesi (3 aded), Ma'den kenarlı tebsi üzerinde Saksonya sahanları (10 aded), ma'den kenarlı tebsi üzerinde pulat kalemkârî

\footnotetext{
62 BOA.TS.MA.d...8127/1/2.

${ }^{63}$ BOA.TS.MA.d...8127/1/2.Osmanlı mutfaklarında kullanılan ve Kuşhâne adını taşıyan bu tencereler saray menşeli bir eşyadır. Kuşhâne esasen Topkapı Sarayı'nda padişahlara ait mutfak olup, mutfak sarayın Kuşhâne isimli kısmında bulunduğu için bu isimle adlandırılmıştır. Burada kullanılan küçük tencerelere aynı isim verilmiştir. Uzunçarşılı, Osmanlı Devleti'nin Saray Teşkilâtı, s.70.
}

${ }^{64}$ Terzi, a.g.e., s.178

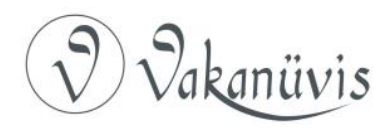


yaldızlı Saksonya sahanları (7 aded), maîli Saksonya sağîr sahan, kebîr Saksonya yemek sahanları (6 aded), Saksonya yemiş tabakları: (maî-6, yeşil-6, elvân-5), Saksonya yaldızlı yemiş tabakları sablı (17 aded), Saksonya tabak (3 aded), Saksonya bardak: Sarı zeminli (2 aded), tirşe (2 aded), laciverd (2 aded), güvez (2 aded), maî (2 aded), beyaz Saksonya bardak (3 aded), rengâmiz yaldızlı Saksonya bardaklar (8 aded), Saksonya çekmece" olmak üzere çok sayıda Saksonya ürünle karşılaşılmaktadır. ${ }^{65}$

Osmanlı konutlarında mevcut olan bölümlerden birisi olan kahve odaları genelde sık kullanılan odaların yakınına yerleştirilmişlerdi. Kahve odalarında özellikle kahve pişirmeye yarayan nesneler bulunsa da, konumlarına göre içerdikleri mefrûşâtın ve kahve takımlarının değerli kumaş ve madenlerden yapıldıkları dikkati çekmektedir. Bu odalarda ayrıca kahvenin yanında ikram etmek üzere tatlı tabağı ve oda ile misafirin güzel kokması için kullanılan gülabdan-buhurdan takımı bulunabilirdi. Yalılardaki kahve odalarının mefruşatına önem verildiği, hanelerdeki kahve odalarının ise servis mekanlarına daha yakın ve daha fazla pişirme ve sunum araç-gereçlerini içerdikleri görülmektedir. Zira bazılarının gümüş gibi değerli madenlerden yapıldıkları, bazılarının belirli bir tarz içeren iş̧̧ilikle adlandırıldıkları, ayrıca süsleme, işleme ve resimler içerdikleri görülmektedir. ${ }^{66}$

Başkadınefendi muhallefâtında söz konusu eşyalar kâse, tepsi, tabak, kavanos, kahve ve tatlı takımları gibi çeşitlere ayrılmaktadır: Bunlardan sahanlar: "Farskârî sahan maa-kapak (7 aded) ve tas, penbe zeminli Farskârî takfon (fakfon) sahan maa-kapak (10 aded), laciverd zeminli kahve altı sahanları maa-kapak (5 aded), taâm sahanları (6 aded), sağîr yemek sahanları (5 aded) lahana resminde sahanlar; kâseler: "Kabartmalı...ufak kase (2 aded), nohudî zeminli (2 aded), Farskârî yaldızlı kapaklı kâse (2 aded) beyaz- mâ̂- lahana resmi,"; tepsiler: "Tebsi (2 aded), pirinç tebsi (2 aded), nuhâs tebsi (2 aded), kebîr tebsi, beyâz ma'den tebsi, kebîrce sarı yemek tebsisi (2 aded)"; tabaklar: "Bayağı tabak (6 aded), bayağı kapaklı ve kapaksız tabak (43 aded)" kahve takımları "Kahve ibriği, askı, hazne, tas, kahve anbarı, gümüş kahve askısı maa- gümüş bakraç (3 aded) fincan (2 aded)"; tatlı takımları ise,

${ }^{65}$ BOA.TS.MA.d...8124-1, 8127-1/2

66 Yavuztürk, a.g.m., s.95

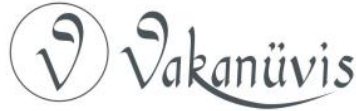


"Hoşab ve tatlı kaşıkları (3 deste), beyaz ma'den tatı hokkası-tebsi ve kaşıkları takım (3 aded), gümüş tatlı hokkası ve beyaz kavanos (30 aded)" olarak kayıtlıdır. ${ }^{67}$ Bu eşyalar arasındaki kavanos veya tatlı kavanoslarının içlerine tatlı besinler konarak muhafaza edilmekteydi. Kavanos, XVIII. yüzyılda lüks bir eşya olarak görülmektedir. ${ }^{68} \mathrm{Her}$ ne kadar Başkadınefendi sahilhânesine ait 1854 tarihli mefruşât defterinde kahve odası adıyla bir odaya rastlanmasa da sahilhânenin üst katında selamlığa yakın veya bitişiğindeki odalardan birisinin bu amaca tahsis edilmiş olması kesin olup, söz konusu eşyalardan bazıları misafir ağırlarken burada kullanılmış olmalıdır.

Başkadınefendi muhallefâtında çeşitli kategorilerde değerlendirdiğimiz eşyalar arasında son olarak temizlikte kullanılanlar gelmektedir. Bu eşyaların bazıları yukarıda vurgulandığı gibi "Matbâh Takımı" başlığıyla mutfak eşyaları ile birlikte, diğer temizlik eşyaları ise defterde öteki eşyaların arasında kaydedilmişlerdir. Sahilhânede kullanılan temizlik eşyalarının: "Ma'den leğen maa-ibrik, ma'den hamam batyası, altun yaldızlı nuhâs el leğeni maa-ibrik, tas (sabun içün), dökme sarı abdest leğeni maa-ibrik, sarı abdest leğeni maa-ibrik, Moskov tenekesinden abdest leğeni ve ibrik (3 parça), dökme abdest leğeni maa-ibrik, sarı leğen (2 parça), nuhâs hamam leğeni, nuhâs leğen maa-ibrik, tombak hamam tası (2 aded), beyaz ma'den kebîr leğen, ibrik (2 aded), sabun anbarı, dökme sarı minkal, altun yaldızı minkal, nuhâs leğen ve ibrik ve çameşuy leğeni ve nuhâs kavanos (6 parça)" olduğu görülmektedir. ${ }^{69}$

Osmanlı yalı veya sahilhânelerinde genellikle mülk sahibinin hamamı ile hizmetlilerin kullandığı hamamlar farklıydı. Buradan hareket edildiğinde sahilhânede sadece Başkadınefendi'nin kullanması muhtemel olan bir hamamın varlığı düşünülebilir. Bu hamamın sahilhânenin alt katında bulunduğu, bir sofa ile geçildiği aynı zamanda soğuk bir camekâna sahip olduğu 1854 tarihli Mefrûşât Defteri aracılığı

\footnotetext{
67 BOA.TS.MA.d...8124-1, 8127-1/2; BOA.TSMA.e...608/28.

68 Yavuztürk, a.g.m., s.96

69 BOA.TS.MA.d...8124/1, 8127/2.
}

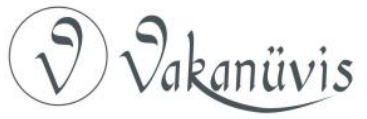


ile tespit edilebilmektedir. ${ }^{70}$ Defterdeki ibarelerden yola çıkıldığında hamamın sahilhânenin ana yapısına bir koridor ile bağlandığı ve kara tarafında bahçe içinde kaldığı akla gelmektedir. Bu bakımdan hamamda kullanılacak eşyalar bahçede mutfağın bir bölümünde muhafaza edilmektedir.

\section{Sonuç}

XVIII. yüzyılın sonlarında dünyaya gelip XIX. yüzyılın ikinci yarısının başlarında vefat eden Hâce Nevfidan Başkadınefendi, cariye olarak girdiği sarayda Sultan II. Mahmud'un eşleri arasına katılarak, Harem-i Hümâyun'un Valide Sultan'dan sonra gelen mevkisi olan Başkadınlığa yükselmiştir. Çeşitli tarihlerde bir şehzâde ve dört sultan dünyaya getiren Hâce Nevfidan Başkadınefendi'nin hiçbir çocuğu yaşamamıştır. Bu sebeple, bir hanedân geleneği olarak Sultan II. Mahmud kendisine kızı Âdile Sultan'ı teslim ederek terbiyesinden sorumlu kılmıştır. Eşi Sultan II. Mahmud'un vefatından sonra bir süre sarayda kalan Başkadınefendi, Âdile Sultan ile birlikte saraydan ayrılıp bir müddet beraber ikâmet etmişlerdir. Sultan'dan ayrıldıktan sonra ise kendisine Hazîne-i Hassa tarafından bir sahilhâne alınmıştır. Ancak sahilhânenin döşetilerek ikâmetine hazır hale getirilmesinden kısa bir süre sonra vefat etmiştir. Vefatıyla sahilhânesi belli şartlar mukabilinde eski Serasker Rıza Paşa'ya tahsis edilmiştir. Sultan II. Mahmud'un Divânyolu'ndaki türbesine defnedilen Başkadınefendi'nin sandukasının bulunduğu kısım kendi ismiyle anılmaktadır. (Nevfidan Kadın Türbesi).

İmparatorlukta batılı tarzda sosyo-kültürel dönüşümün başladığı tarihlerde vefat eden Başkadınefendi'nin hayatı, faaliyetleri ve şahsiyetine dair kaynaklarda fazla bilgi bulunmamaktadır. Nitekim yapılan incelemede devletin resmi yayın organı olan Takvîm-i Vekayi' dahil olmak üzere dönemin gazetelerinde Başkadınefendi'ye dair vefat veya başka bir hususu içeren herhangi bir bilgiye rastlanmamıştır. Bununla birlikte kaynaklara göre hayırsever ve dindar bir şahsiyete sahip olduğu tespit edilen Hâce Nevfidan Başkadınefendi, saraylılar arasında hacca giden ender şahıslardan birisidir. Bu özelliği onu hanedan içinde

70 " Hamam yolunun üstünde tarafeyni döşemeli odalar/ Alt katda soğuk camekân ittisâlinde odalar/Hamam ve soğuk camekân" TS.MA.d...7916-7-9; Yavuztürk, a.g.m., s.96

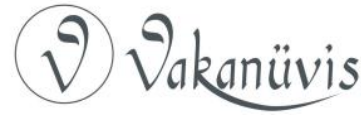


ön plana çıkarmıştır. Aynı zamanda Mekke ve İstanbul'da çeşitli vakıflar kurmuş, yine vakıf faaliyetleri doğrultusunda sıbyan mektebi ve cami gibi eserler yaptırmıştır. Ancak bu vakıfların günümüze gelmediği ve eserlerin XX. yüzyılın ilk yarısına kadar varlıklarını sürdürebildikleri görülmektedir.

Hâce Nevfidan Başkadın Efendi'ye padişah eşi saraylı bir kadın olması hasebiyle oturması için Boğaz'ın Anadolu yakasında bulunan Beylerbeyi semtinde bir sahilhâne veya yalı tahsis edilmiştir. İki katlı ve altında bir kayıkhânesi bulunan sahilhânenin dönemin diğer benzer yapılarıyla aynı nitelikleri taşıdığı anlaşımaktadır. Burada Başkadınefendi'ye cariyeleri, hizmetçileri ve sahilhânede görev yapan personel eşlik etmektedir. İç yapısı değerli kumaşlarla döşeli olan sahilhâne Osmanlı sosyal ve kültürel yaşamının temel kuralları dahilinde, harem ve selamlık olarak ikiye ayrılmıştır. Üst sınıfa mensup diğer kişilere ait benzer konutlardaki gibi, misafirlerin karşılanacağı, ağırlanacağı odalar mevcut olup, odalar aynı zamanda işlevlerine göre mabeyn, koltuk odası, divânhâne, sofa vb. gibi isimlerle adlandırımıştır. Odalar mefruşat defterinde aynı zamanda boyaları ve tavan ve döşeme gibi kısımlarındaki renklerle tanımlanmışlardır. Alt katta bulunan ve bir koridorla geçilen hamamın sadece Başkadınefendi'ye ait olduğu düşünülmektedir. Dönemin diğer sahilhâneleri gibi mutfak dışarıda olmalıdır. Sahilhâne personeli ve çeşitli hizmetlerde istihdam edilenler, kendilerine ayrılan kısımlarda kalmakta olmalıdırlar.

Başkadınefendi'nin vefatından sonra kaydedilen muhallefât defterlerinde mal varlığına dair detaylı dökümler bulunmaktadır. Bu mallar arasında değer bakımından ilk sırada mücevherleri ve değerli eşyaları gelmektedir. Nitekim bunlar vefatından sonra saraya alınmış ve muhtemelen Sultan Abdülmecid tarafından bazı saraylı kadınlara hediye olarak ihsan edilmiştir. Defterlerdeki kayıtlarda Başkadınefendi'nin mücevherlerinin fazla sayıda olmaması dikkat çekmektedir. Bu durum yaşamı boyunca elde ettiği mücevherlerin ve gelirlerin çoğunu hayır işlerine harcamasıyla ilgili olabilir. Ayrıca bazılarını cariyelerine ve hizmetçilerine bağışlamış olması mümkündür.

Başkadınefendi muhallefâtında dikkati çeken diğer bir husus ise mücevherleri gibi geride bıraktığı giysilerinin azlığıdır. Harem-i Hümâyûn'da Valide Sultan'dan sonra ikinci sıraya yükselmiş bir saraylı 
olmakla birlikte, giysileri arasında değerleri açısından sadece kürkler dikkat çekmektedir. Defterlere göre diğer giysileri sadedir. Bu örnekle birlikte, kendisinden sonra aynı mevkiye gelen Sultan Abdülmecîd'in Başkadınefendi'si Servetsezâ Kadınefendi'ye ait 348 pamuklu, 307 ipekli, 112 adet yünlü giysi tespit edilmiş olması dikkat çekmektedir. ${ }^{71}$ Ancak, Hâce Başkadınefendi'nin kayda geçirilenlerden daha fazla elbisesi ve eşyası olması, bunları vefatı öncesinde hizmetindeki cariye ve halayıklarla sahilhânesinde görev yapan kişilere dağıtmış olması muhtemeldir.

Başkadınefendi muhallefâtında giysiler ve mücevherlerden sonra kumaşlar gelmektedir. Sahilhâne döşemelerini teşkil eden ve çeşitli intiyaçlar için kullanılan kumaş ve bezlerin top ve adet şeklinde kayıtlı oldukları görülmektedir. Bazılarının elbise yapımında kullanılmak için alınmış olmaları muhtemeldir. Muhallefatta ismi geçen tekstil mamullerinin çoğu ipekli ve belli bir değer sahibi türlerdeki kumaş ve bezlerdir. Bazıları el işi olup, sırma ve tellerle süslenmiştir.

Başkadınefendi'nin geride bıraktığı eşyalar arasında kumaş ve bezleri takiben ev içinde, mutfak ve hamamda kullanılanlar gelmektedir. Bu eşyalardan bazıları, yine bazı kumaş ve bezler gibi değerli olup çeşitli madenlerden imal edilmişlerdir. Bunlar arasında şamdan, güllabdan, buhurdan, mangal, tepsi, sini, tabak, sahan, mangal, sofra, saat, sandık vb.mevcuttur. Bazıları yaldızlı olup, ahşap, bakır, sim, pirinç vb. maden ve maddelerden imal edilmişlerdir. Başkadınefendi'nin XIX. yüzyılın ilk yarısından itibaren Osmanlı saray çevreleriyle seçkin çevrelerde popüler olan Saksonya menşeli mutfak malzemelerine dikkat çekici bir sayıda sahip olduğu görülmektedir. Tepsi, maşraba, tabak, sahan, bardak, üsküre, kase vb. türleri olan Saksonya eşyalar aynı zamanda yaldızı ve kalemkari olup, bu nitelikleri değerlerini artırmaktadır. Saksonya menşeli olanlarla ve gündelik yaşamda kullanılan eşyalar gibi aynı şekilde değerli maden ve maddelerden yapılmış başka mutfakta ve gündelik ihtiyaçlarda kullanılan eşyalara da rastlanmaktadır. Bunlardan bazılarının aydınlatma, ısınma vb. ihtiyaçlar için kullanılırken, bazıları sahilhânenin sofrasını süslemektedir. Bunlarla birlikte muhallefât kalemleri arasında görülen temizlik ve benzer hizmetlerde kullanılan eşyalar hem daha sade, hem de sayıca daha azdır. Hamamda kullanılan

71 Yılmaz, a.g.m., s.1079.

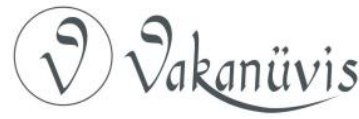


bu eşyaların diğer Osmanlı konutlarında kullanılanlarla benzer nitelikte olduğu görülmektedir.

Muhallefât defterlerinde son kaydedilen kalemlerin ise bahçede kullanıldığı anlaşılan bazı hayvanlarla, yakacaklar olduğu görülmektedir. Hayvanlar arasında ismi geçen dolap beygirinin varlığı bahçede bir su kuyusunun bulunduğunu göstermektedir. Muhtemelen bahçenin bir kısmı ekilmekte olabileceği gibi çiçeklerle ve meyve ağaçlarıyla süslenmiş olması mümkündür. Buranın idaresi sahilhâne personeli arasında bulunan bir bahçıvana bırakılmış olmalıdır.

Netice itibarıyla, Osmanlı sarayında batılılaşma rüzgarlarının etkisini göstermeye başladığı dönemlerde vefat eden Hace Nevfidan Başkadın Efendi, dindar ve hayırsever bir ömür geçirmiş ve sahip olduklarının çoğunu muhtemelen bu yolda harcamıştır. Bir saraylı kadın olması hasebiyle, diğer seçkin sınıf mensuplarının yaşam standartına sahip olan Başkadınefendi, aynı zamanda hatırı sayılır bir muhallefâta sahiptir. Kendisine tahsis edilen sahilhânesinde hizmetçileri, cariyeleri ve diğer personel ile ömrünün son yıllarını geçirmiştir. Vefatından sonra tespit edilerek Hazine-i Hassa'ya alınan muhallefâtı ilerleyen tarihlerde yaptıkları harcamalarla devletin mali buhran içine girmesine sebebiyet veren ve Sultan Abdülmecid tarafından bu nedenle uyarılan sultanlara nazaran ${ }^{72}$ mütevazidir. Ancak, XIX. yüzyılın ikinci yarısında Osmanlı sosyo-ekonomik ve kültürel hayatı hakkında yapılacak diğer çalışmalar, bu hususta daha net ve sağlıklı karşılaştırmaların yapılabilmesinin yolunu açacaktır

\section{Kaynakça}

\section{Arşiv Kaynakları}

TC. Cumhurbaşkanlığı Arşivi Cumhuriyet Arşivi (BCA)

Başbakanlık Kararlar Daire Başkanlığı

Nr.154-68-3

TC. Cumhurbaşkanlığı Arşivi Osmanlı Arşivi (BOA)

A.MKT.(Sadâret Mektubî Kalemi)

$\mathrm{Nr}: 115 / 15,155 / 15$,

72 Akyıldız tarafından "mü'min ve müsrîf" olarak adlandırılan Sultan Abdülmecid'in kızlarından Refia Sultan'ın terekesi için Akyıldız, a.g.e., s.156-180.

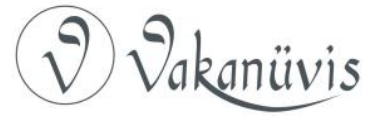


A.MKT. MHM. (Sadaret Mektûbî Mühimme Kalemi)

Nr. 20/40

BEO( Bâb-ı Âlî Evrak Odası)

Nr.2084/156270

C..EV..(Cevdet Evkaf)

Nr.537/27126

EV.d...(Evkaf Defterleri)

Nr.12420, 20650

MF.IBT. (Mâarif Nezâreti Tedrisât-ı İbtidâiye Kalemi)

Nr.252/11,295/80

ŞD. (Şurâ-yı Devlet)

Nr.161/7

TS.MA.d...(Topkapı Sarayı Arşivi Defterleri)

Nr. 521, 5102, 7916, 8124, 8127

PLK.p...(Plan-Proje-Kroki)

Nr.384

TS.MA.e...(Topkapı Sarayı Arşivi Evrak)

Nr. 601/75, 603/69, 603/76, 603/89, 608/28, 612/31, 1114/28, 1206/65

Y..A...RES.(Yıldız Resmî Marûzât)

Nr.119/91

TT: Taha Toros Arşivi

Nr.501451

\section{Kitap ve Makaleler}

Alderson, A. Dolphin, Bütün Yönleriyle Osmanlı Hanedanı, Birinci Baskı, İz Yayıncılık, İstanbul, 1998.,

Akyıldız, Ali, Mümin ve Müsrif Bir Padişah Kızı Refia Sultan, Tarih Vakfı Yurt Yayınları, İstanbul, 1998.

Argıt, Betül İpşirli, Gülnuş Emetullah Valide Sultan, (1640-1715), Kitap Yayınevi, İstanbul, 2014.

Bozkurt, Fatih, "Osmanlı Dönemi Tereke Defterleri ve Tereke Çalışmaları" Türkiye Araştırmaları Literatür Dergisi, C.11, S.22, İstanbul, (2013), ss.193-229.

Buzpınar, Ş. Tufan, "Surre” TDVIA. C.37, İstanbul, (2009), ss.567-569.

Civan, Celil, İstanbul'un Yüz Türbesi, İstanbul Büyükşehir Belediyesi Kültür AŞ. Yayınları, İstanbul, 2013.

Haskan, Mehmed Mermi, Yüzyıllar Boyunca Üsküdar, C.2, Üsküdar Araştırmaları Merkezi Yayınları, İstanbul, 2001.

Kolay, Arif "Hayırsever, Dindar Nazik ve Şaire Bir Padişah Kızı: Adile Sultan”, Akademik incelemeler Dergisi, C.12, S.2, Sakarya, (2017), ss.1-33.

Küpeli, Özer, "Kösem Sultan'a Ait Bir Muhallefât Kaydı" Cihannüma Tarih ve Coğrafya Araştırmaları Dergisi, S.I/2, İzmir, (2015), ss.131-143

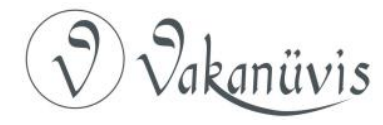


Mehmed Süreyya, Sicill-i Osmânî, C-I, Haz. Nuri Akbayar, Tarih Vakfı Yurt Yayınları, İstanbul, 1996.

Pakalın, M. Zeki, Osmanlı Tarih Deyimleri ve Terimleri Sözlüğü C.II, Birinci Baskı, İstanbul, 1993. , Osmanlı Tarih Deyimleri ve Terimleri Sözlüğü C.III, İstanbul, 1993.

Sağır, Yusuf, "Valide Turhan Sultan'ın Muhallefâtı" Çanakkale Araştırmaları Türk Yıllığı Dergisi, S.20, Çanakkale, (2016), ss.265-328.

Sarıbal, İsmet, “Pertevniyal Valide Sultan'ın El Konulan Hazinesine Dair Tutulan Bir Defterin Analizi" Cihannüma Tarih ve Coğrafya Araştırmaları Dergisi, S.IV/1 İzmir, (2018), ss.131-154

Sakaoğlu, Necdet, Bu Mülkün Kadın Sultanları, Alfa Tarih Yayınları, İstanbul, 2015.

Sefer, Nurcan-Ahunbay Zeynep “Eminönü’nün Haliç Kıyı Bölgesindeki Vakıf Kültür Mirası'nın 1920-2015 Arasında Geçirdiği Onarımlar ve Uğradığı Kayıplar, Restorasyon Yıllığı Dergisi, S.10 İstanbul, (2015), ss.78-120.

Şehsuvaroğlu Haluk, Y. "Tarihten Sayfalar" Akşam Gazetesi, 1949.

Öztuna, Yılmaz, Devletler ve Hanedanlar, C.II, Kültür ve Turizm Bakanlığı Yayınları, Ankara, 2005.

Tekin, Rahmi "Osmanlı'da Üç Hanım Sultanın Ziynet Eşyası" Bingöl Üniversitesi Sosyal Bilimler Dergisi" C.8, S.15, Bingöl, (2018), ss.297-316;

Terzi, Arzu, Hazine-i Hassa Nezâreti, TTK. Yayınları, Ankara, 2000. , Bezmialem Valide Sultan, Timaş Yayınları, İstanbul, 2018.

Uluçay, M.Çağatay, Harem, Ötüken Yayınları, İstanbul, 2013. Haremden Mektuplar, Ötüken Yayınları, İstanbul, 2012.

Uzunçarşılı İsmail Hakkı" Abdülhamid Ferid Paşa'nın Ruznâmesinden" Belleten, XXVII, S.106, Ankara, (1963) ss.257-288.

Yayınları, Ankara, 1988.

, Osmanlı Devletinin Saray Teşkilatı, TTK.

Yavuztürk, Ş. Pınar, "Bir Müfettişin Defterinden Üsküdar Sıbyan Mektepleri", Uluslararası Üsküdar Sempozyumu-VI Bildiriler, C.II, Üsküdar Belediyesi Yayınları, İstanbul, (2007), ss.553-568.

"Bir Osmanlı Cariyesinin Şahsi Eşyaları: "Sarayî Emetullah Hatun" Kültür, S.16, İstanbul, (2016), ss.28-31.

Yılmaz, Serap "Saraylı Bir Kadının Gardrobu (19.yy)" XIII. Türk Tarih Kongresi, C.III, TTK. Basımevi, Ankara, (1998), ss.1073-1083. 


\section{Ekler}

\section{Ek-I/Belge-I}

Hâce Nevfidan Başkadınefendi'ye ait Muhallefât Defteri BOA. TS.MA.d...8124/1

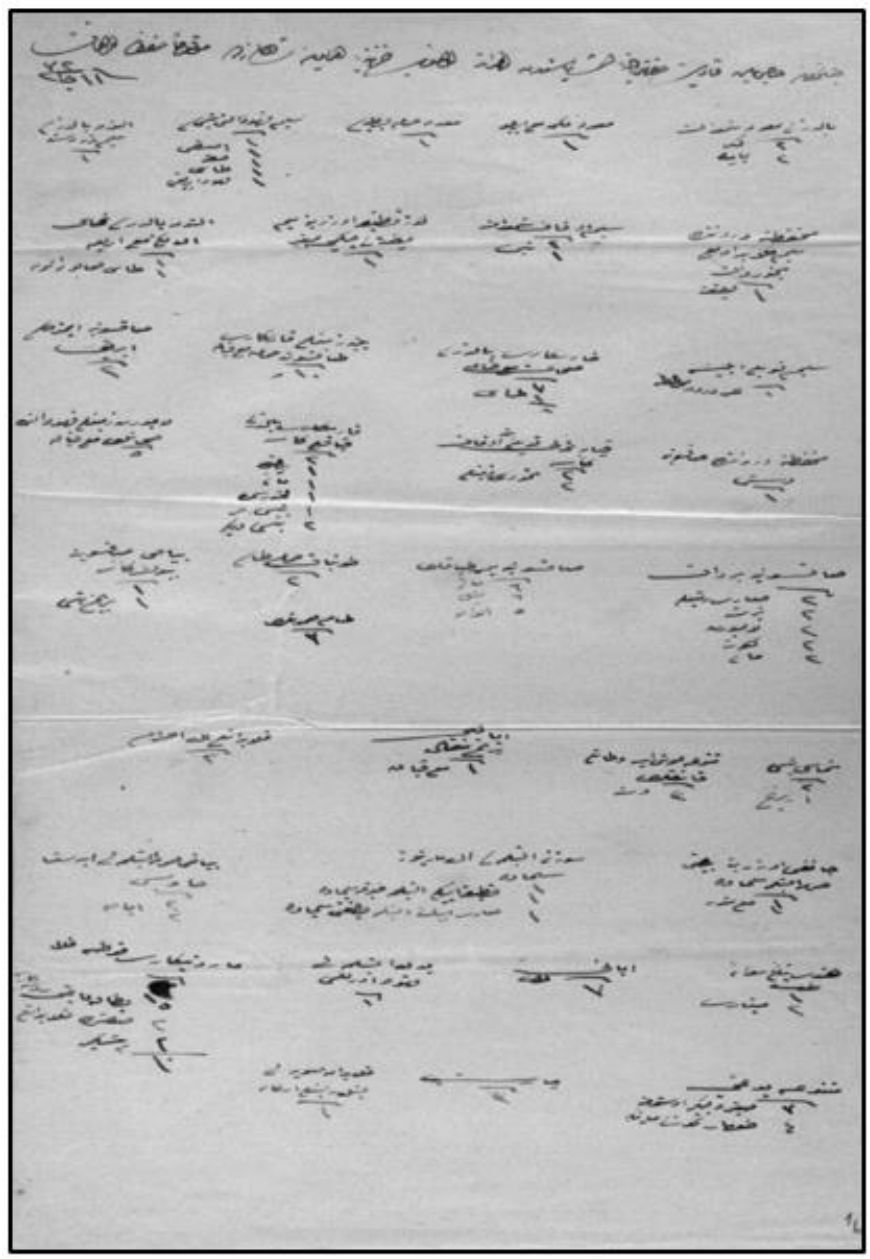




\section{Ek-II/Belge-II \\ Hâce Nevfidan Başkadınefendi'ye ait Muhallefât Defteri \\ BOA. TS.MA.d...8127/1-2}

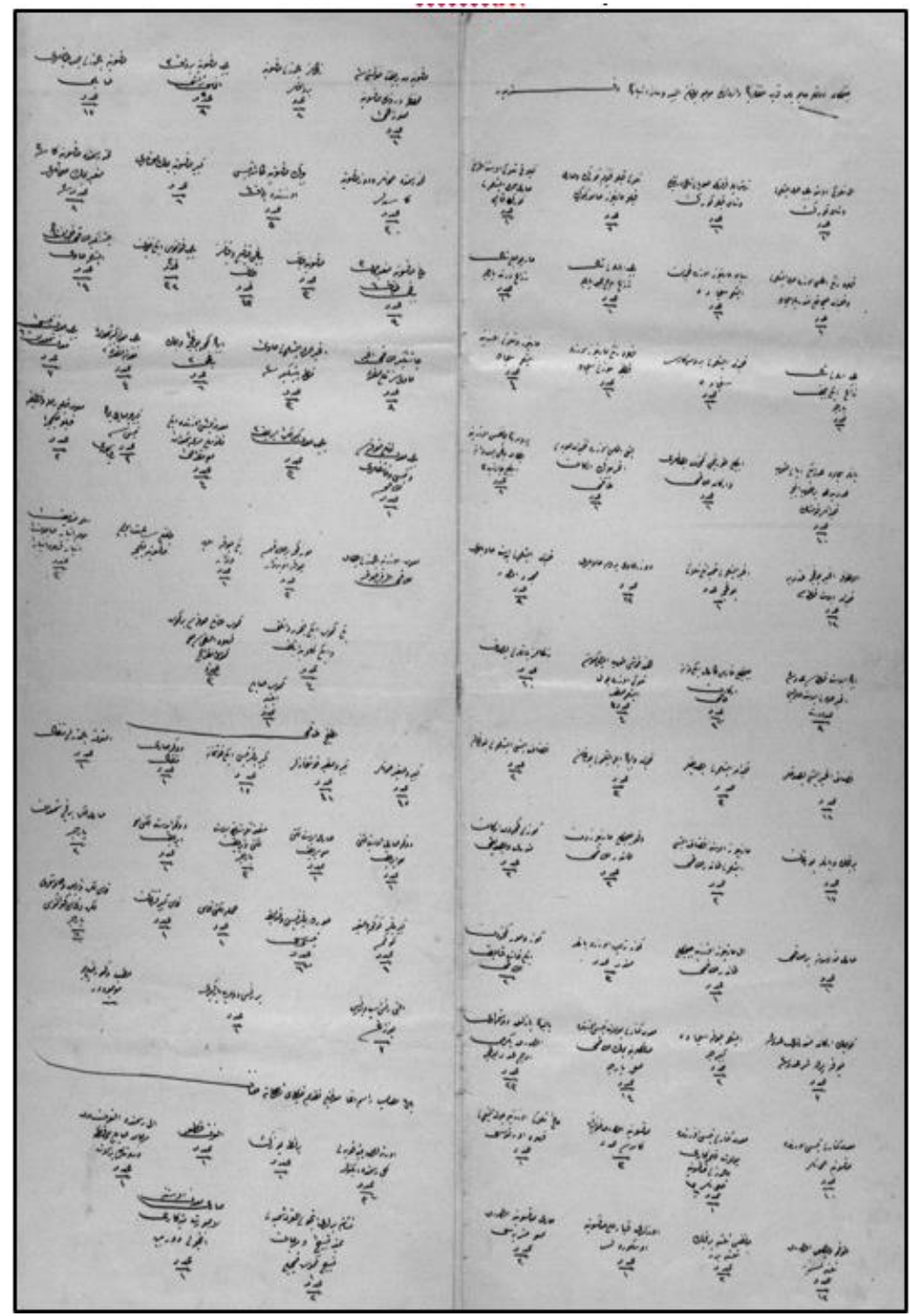

(2) Vakanüvis 


\section{Ek-III/Transkript-I \\ Hace Nevfidan Başkadınefendi'ye ait Muhallefât Defteri \\ BOA. TS.MA.d...8124/1}

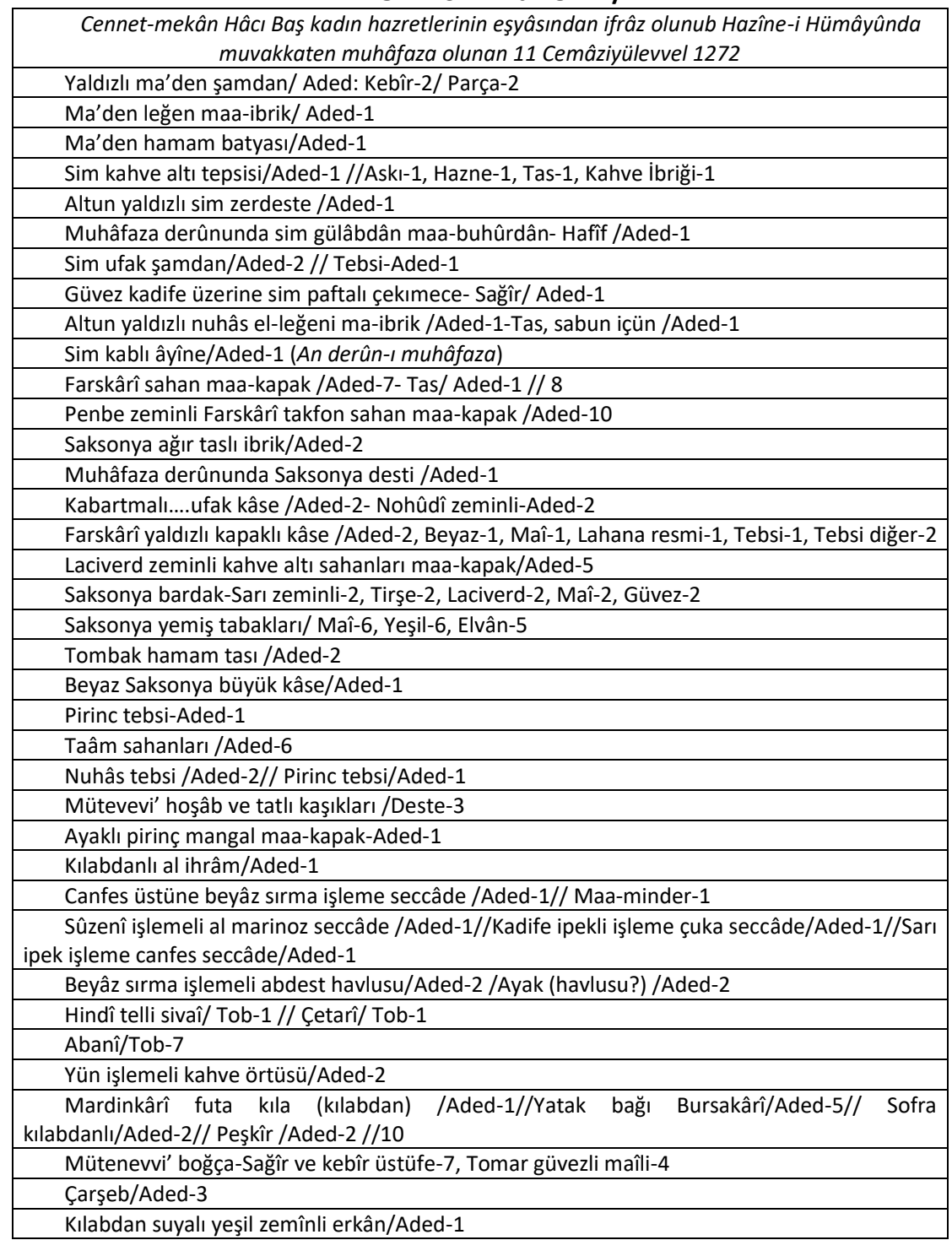




\section{Ek-IV/Transkript-II \\ Hace Nevfidan Başkadınefendi'ye ait Muhallefât Defteri \\ BOA. TS.MA.d...8127/1-2}

\begin{tabular}{|c|}
\hline Al şâlâkî üstüne beyâz sırma işlemeli vaşak kürk/Aded-1 \\
\hline Tirşe ile kırmızı suyalı derûnunda vaşak kablı kürk /Aded-1 \\
\hline Şâlâkî kaplu kayum (kakum?) kürk ve sarı kablı merinoz samur kürk/Aded-2 \\
\hline Leylaki şâlâkî üstüne etrafı sarı sırma işlemeli kürk kabı/Aded-1 \\
\hline Kahverengi atlas üzerine sırma işlemeli ve kılabdan saçaklı minderiyle seccade/Aded-1 \\
\hline Siyah merinoz üzerine kılabdan işleme seccade/Aded-1 \\
\hline Beyaz armalı şâlî zirâ' üç buçuk parça/Aded-1 \\
\hline Marpuçlu şâlî zira dört parça /Aded-1 \\
\hline Beyaz armalı şâlî zirâ'-iki buçuk, parça/Aded-1 \\
\hline Kılabdan işlemeli Burusakârî seccâde/Aded-1 \\
\hline Kahverenkli merinoz üzerine kadife sûzenî seccâde/Aded-1 \\
\hline Merinoz ve şâlâkî üzerine işleme seccâde/Aded-4 \\
\hline Yazma seccâde /Aded-2//Âbâni tob /Aded-7// ve 1 tob ince kılabdanlı kuşak /Aded-10 \\
\hline İpekli turuncu kemhâdan yasdıkları ve erkân takımı/Aded-1 \\
\hline Yeşil atlas üzerine kılabdan suyalı ağır büyük erkân takımı/Aded-1 \\
\hline Burusanın canfesi üzerine yatak bağı beş dâne/ İpekli çarşeb-3//Aded 8 \\
\hline Üstüfe ağır boğça/ Aded-1//Kılabdan abdest futası/Aded-12 \\
\hline Ağır işlemeli kılabdanlı şâlâkî boğça/Aded-1 \\
\hline Düz rehâvî? Burusa sevbleri/Aded-24 \\
\hline Kılabdan işlemeli abdest sevbleri mücedded.../Aded-9 \\
\hline İpek abdest futası- Aded-5//Ağır sırmalı abdest havlusu-Aded-4/ Aded-9 \\
\hline Çiçekli Farskârî iki dâne erkân takımı/ Aded-2 \\
\hline Hind Kumaşı tob-3/ Gümüş şâlâkî üzerine pul işleme sofra/ Aded-1 / Aded-4 \\
\hline Rengâmîz yazmalı yasdık/Aded-20 \\
\hline Kılabdan işlemeli yasdıklar/Aded-3 \\
\hline Kılabdan ve ipek ile işlemeli yorgan/Aded-3 \\
\hline Kasnak işi işlemeli yorgan/Aded-2 \\
\hline Birincek (bürümcük) ve yazma yorgan/Aded-17 \\
\hline Marinoz üzerine kasnak işi işlemeli tandır takımı/Aded-2 \\
\hline Def'a çiçekli merinozdan tandır takımı/Aded-2 \\
\hline Güvezli kemhâdan erkân minderi ve yasdığı/Aded-2 \\
\hline Sarı harsdan (harç?) yer takımı/Aded-1 \\
\hline Al marinoz üzerine çiçekli tandır takımı/Aded-1 \\
\hline Saksonyadan bir çift su testi-1 /Muhâfaza derûnunda Saksonya sürahi-1/Aded-1 \\
\hline Rengâmîz yaldızlı Saksonya bardaklar/Aded-8 \\
\hline Beyaz Saksonya bardak-3//Elmas traş-3/ Aded-9 \\
\hline Saksonya yaldızlı yemiş tabakları sablı /Aded-17 \\
\hline Lahana resminde sahanlar ve düz Saksonya kâseler/Aded-30 \\
\hline Büyük Saksonya kâse-1/Tebsi üzerinde bardak-4/Aded-5 \\
\hline Kebir Saksonya yemek sahanları/Aded- 6 \\
\hline Lahana resminde Saksonya kâse-3/Sağir yemek sahanları-5/Aded-8 \\
\hline Maili Saksonya sağîr sahan-3/Bayağı tabak-6/Aded-9 \\
\hline Saksonya Tabak/ Aded-3 \\
\hline Bayağı kapaklı ve kapaksız tabak/ Aded-43 \\
\hline Beyaz kavanos Aded-30/iki fincan /Aded-32 \\
\hline
\end{tabular}


Çâşnîgîr takımı kılabdan ipek işleme havî/Aded-14

Çâşnîgîr takımı/Ağır havî tırtılı sofra/Aded-9

Ağır sırma işlemeli havî-1/Futa peşkîr-2/Aded-3

İpek kemhâ boğça-4/Yatak bağı-2/Aded-6

\section{Ek-V/Transkript-III: Hace Nevfidan Başkadınefendi'ye ait Muhallefât Defteri BOA. TS.MA.d...8127/1-2}

Beyaz ma'den kebîr şamdan-2/ Ma'den sofra-2/Aded-4

Beyaz ma'den tebsi-1/Ma'den şamdan-6/Aded-7

Beyaz ma'den tatlı hokkası ve tebsi ve kaşıkları takım/Aded-1

Beyaz ma'den kebîr leğen-1, ibrik-2/Aded-3

Ma'den tebsi-2-Üzerinde iki fanuslu müressem şamdan maa-makras-1/Aded-3

Kebîrce sarı yemek tebsisi/Aded-2 (Biri geldi)

Maûn kablu rahle ve kadife kablu çekmece-1/Aded-2

Maûn üzerine yaldızlı yatak takımı etrafı çuka

Mor kemhâ bir takım çuka urba?-1 ve 1 zâr/ Aded-3

Yeni çuka urba ve zâr-1/Aded-1

Çalgılı sâat/Aded-3// Saksonya Çekmece

Sim sandık-1/Mum anbar-1/Sabun anbar-1/Kahve anbar-1/Aded-3

Yeni gümüş iki buhûrdânlık ve iki gülâbdânlık/Aded-4

Gümüş tatılı hokkası/ Bir gümüş kahve askısı maa-gümüş bakraç/Aded-3

Gümüş sablı âyîne Aded-1

Kebîr ve sağir sahanlar/Aded-45

Kebîr ve sağîr kuşhâneler/Aded-41

Kebir bakır tebsi/ iki kuşhâne/Aded-17

Dökme sarı minkal/Aded-1

Altun yaldızlı minkal/Aded-1

Dökme sarı abdest leğeni maa-ibrik/Aded-1

Sarı abdest leğeni maa-ibrik Aded-1

Sarı leğen pirinç şamdan parça-2

Kebîr bakır güğüm ve sağîr güğüm/Aded-6

Hurde bakır tebsi ve kadaif tebsisi/Aded-6

Hamam leğeni nuhâs/Aded-1

Nuhâs kebîr kazgan/Aded-1

Nuhâs leğen maa-ibrik

Nuhâs leğen ve ibrik câmeşûy leğeni ve nuhâs kavanos parça/Aded-6

Altı re's esb ve bir re's buzağı/Aded-7

Bir re's dolâb bârgîri

Hatab ve kömür haylice mevcûddur.

Baş musahîb Râsim ağa marîfetiyle takdîm-i hâk-i pay-i şâhâne kılınan

Ortaları penbe kübeli gül resminde iğneler/Aded-3

PIrlanta yüzük/Aded-1

Altun kut-Aded-1

El resminde altundan mercan sablı muhâfaza derûnunda bir alet/Aded-1

Nişân yerleri incüli altun şemsiyeli ağır tesbîh ve mercan tesbîh gümüş kamçוlı/Aded-2

Sarı ma'den üstüne laciverd minekârî incüli dürbîn 


\section{Ek-VI/Transkript-IV \\ Başkadınefendi'ye Ait Bazı Sehmler ve Verildikleri Tarihler}

TS.MA.d...5112-1

Nevfidan Kadınefendi Hazretlerinin Uhdesinde olan Sehâmı

Nezâret-i Midillü Mukataası Eshâmından

Fâiz: Fey-5000 guruş

(Taksît-i evveli Kanûn-ı evvel sânîsi Nîsân ibtidâsında)

İzmir Cizyesi Eshâmından

Fâiz: Fey-500 guruş

(Taksît-i evveli Mart sânîsi üç mâh mürûrunda Hazîran

ibtidâsında)

Siroz Cizyesi Eshâmından

Fâiz: Fey-1.500 guruş

(Taksît-i evveli Hazîran sânîsi Kanûn-ı evvel ibtidâsında)

\section{Ek-VII/Transkript-V}

Başkadınefendi'nin Surre İçin Tahsis Ettiği Sehmin Beratı ve İlmuhaberinin Verildiği

BOA.A.MKT.MHM.20/40

Mâliye Nâzırı Hazretlerine

Cennetmekân efendimiz hazretlerinin başkadını devletlû ismetlû Hâce Nevfidan Kadınefendi hazretlerinin uhde-i âlîyelerinde bulunub Medîne-i münevvere ahâlî-i kirâmına tevzî́ ve taksîm olunmak üzere tahsis buyurdukları sehmin (1) berâtıyla mukaddem virilen ilm u haber kaimesi ve müşarûhileyâ hazretlerinin mührleri leffen su-yi vâlâlarına gönderilmiş ve icabının hin-i icrâsı lâzımeden bulunmuş olmağın hazinece iktizasının sür'at-i tesviyesi husûsuna... olunub/

Faîzinin mevsîm-i hâccda Cidde hazinesinden i'tâ olunması ifâde

Sâadetlû Kâtib Beg Efendi hazretlerine ifâdesiyle

Tarih H. 4 Cemazîyülâhir 1266/M.17 Nisan 1850

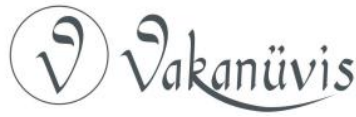




\section{Ek-VIII/Transkript-VI \\ Nevfidan Kadın Camii Hitâbet Ciheti Tevcîhi}

$$
\text { C..EV..537/27126 }
$$

Derâliyye' de Bâb-ı Hatab hâricinde Hadîce Hâtûn Cami'-i Şerîfi'nin ber vechi hasbî hitâbet cihetine Ömer Efendi'nin ba-berât-ı âlî uhdesinde olduğu vâkıf-ı müşarûnileyhânın bin iki yüz altmış yedi senesiyle müverrâh mukayyed olan vakfiye-i me'mûl-bahâsında ma'dûd mevkûfesinden hâsıl olan rıbh u nemasına mahmîye-i İstanbul'da Hatab Kapusu harîcinde müceddeden binâ' eylediği mumâileyhâ Hadîce Hâtun Cami'-i Şerîf'inde hatîb olanlara şehriye on beş guruş verile deyû şart ve ta'yîn eylediği mestûr ve musarrah olub ve meâl-i istidâ zikr olunan hitâbet ciheti merkûmun mahlûlünden ve oğullarının adem-i ehliyetinden sâhib-i arz-ı hâl merkûma tevcihinden ibâret olub ve kuyûd-ı lâzımesi dahi ihraç kılınmış olmağla bu sûretde meâl-i istidâ ve mücedded derkenârda tezkiren keyfiyeti ilâm olunmağla lüzûmı üzre Evkaf-ı Haremeyn Müfettişi fazîletlû efendiye havâlesi bâbında fermân hazret-i men leh'ülemrindir.

H.25 Safer 1272/M.6 Kasım 1855

\section{Ek-IX//Resim-I}

Sultan II. Mahmud Türbesi Dahilinde Nevfidan Türbesi Olarak Adlandırılan Kısım (www.turkiyenintarihieserleri.com)
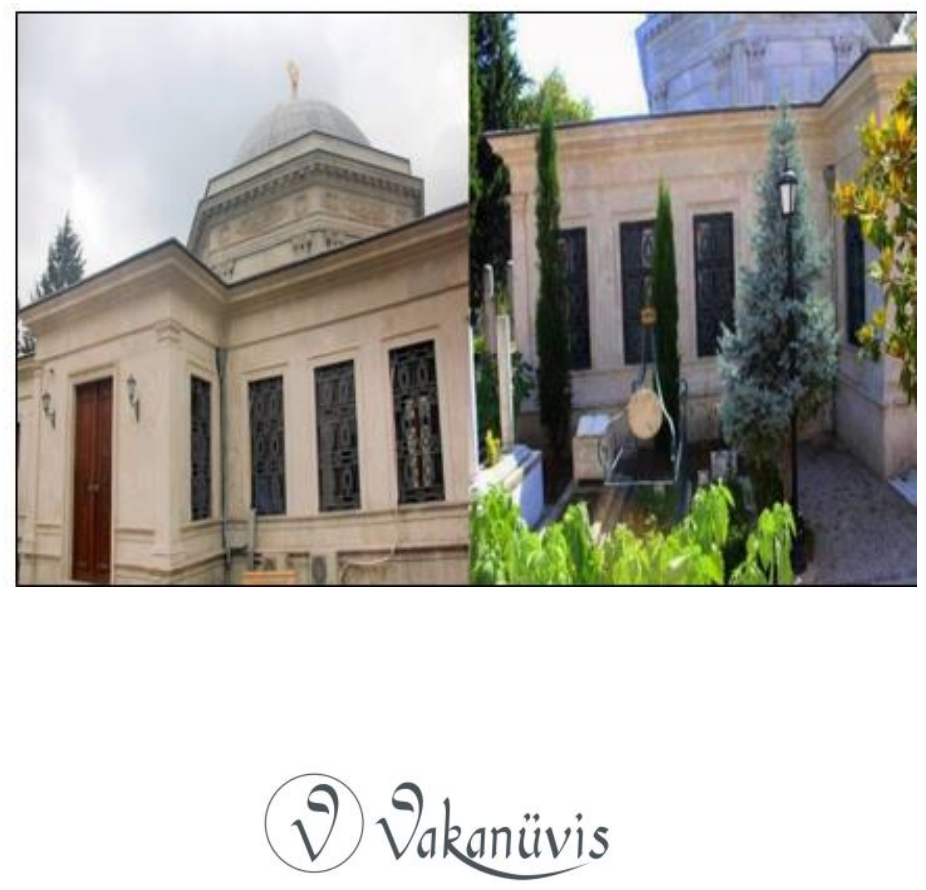


\section{Ek-X/Resim-II}

Restorasyon Sonrası ve Öncesinde Nevfidan Türbesi'nden İç Görünüm (www.semerkânttanbosnaya.com)

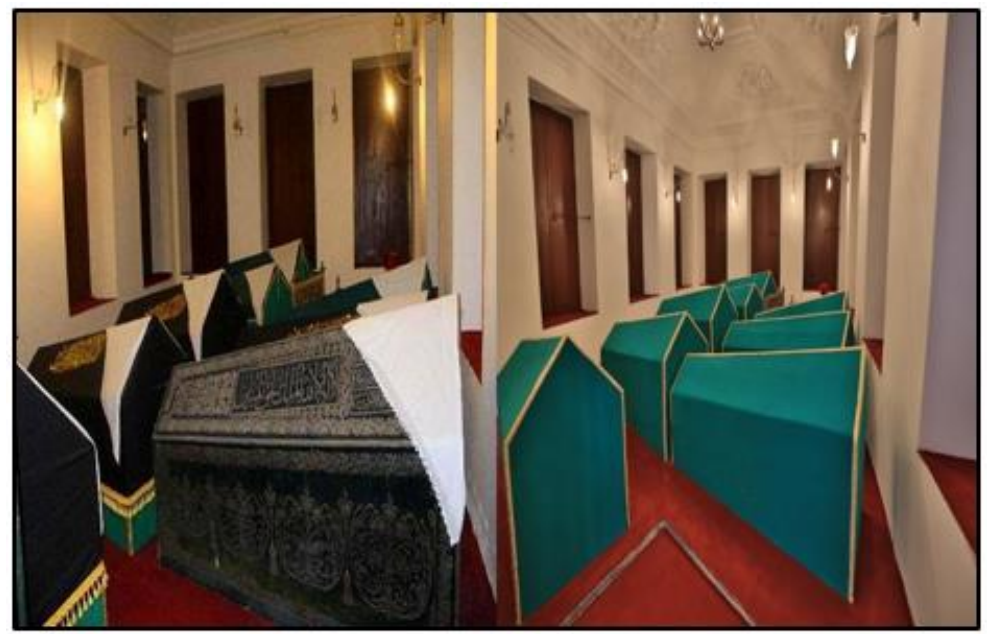

\section{Ek-XI /Resim-III}

Hatab Kapusu' nda Yanan Nevfidan Kadın Cami'nin Yeniden İnşası İçin Hazırlanan Plan/ BOA.PLK.p...384
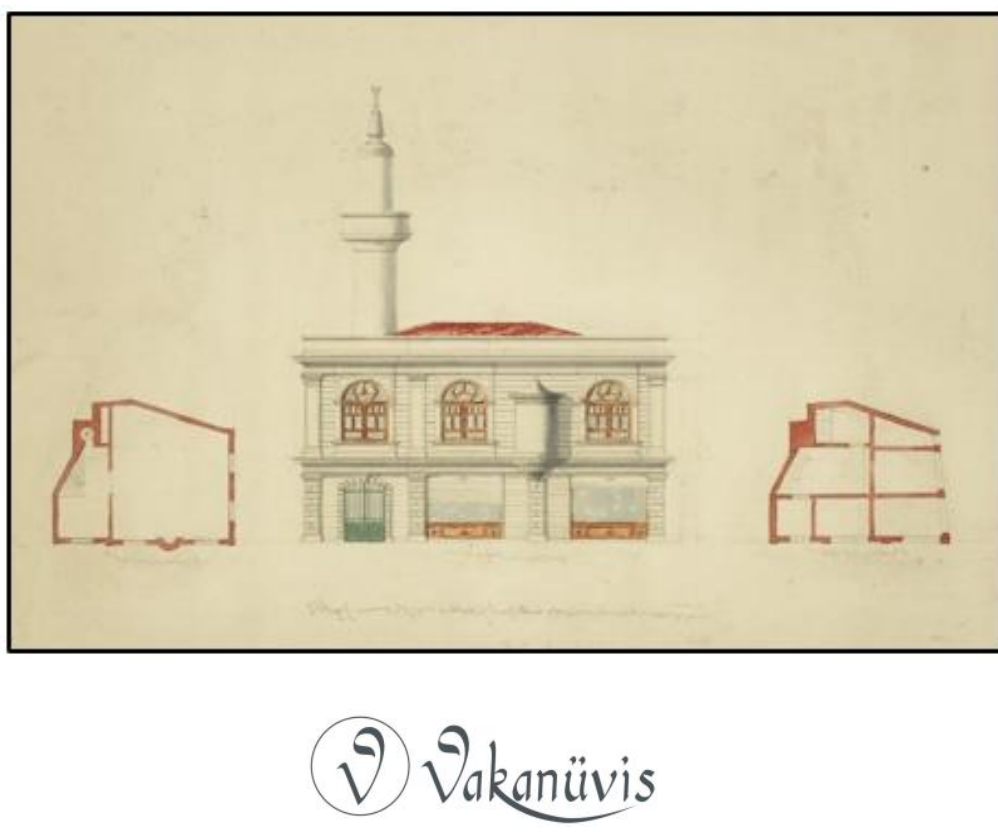


\section{Ek-XII/Resim-IV \\ Nevfidan Cami'nin Konum ve Mevkisi}

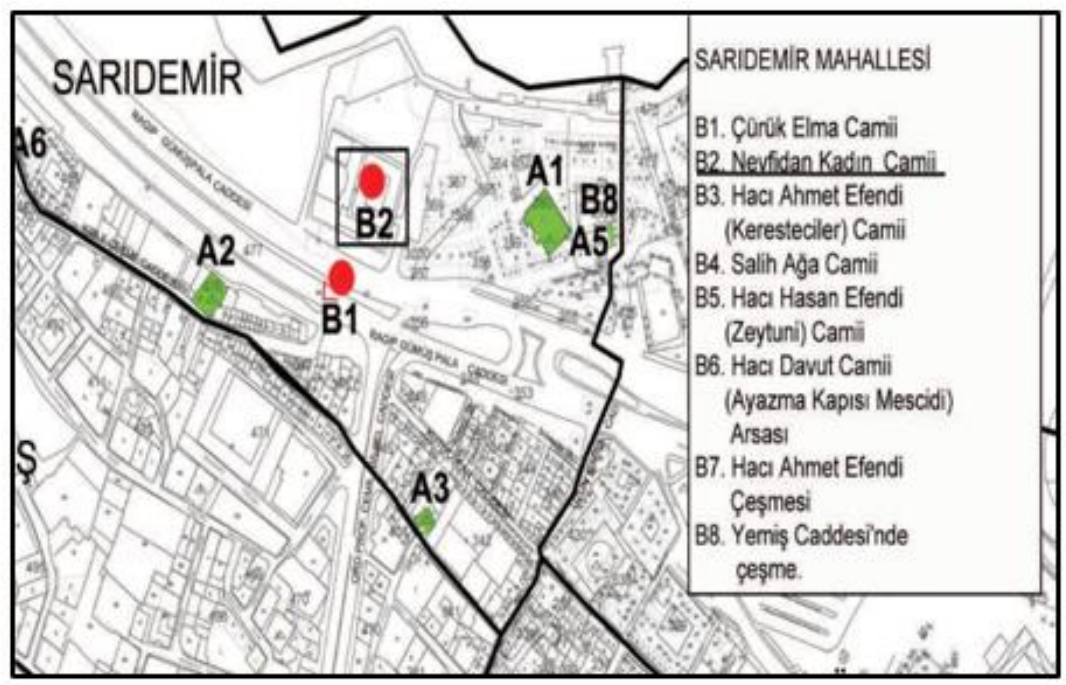

(Nurcan Sefer- Zeynep Ahunbay. "Eminönü'nün Haliç Kıyı Bölgesindeki Vakıf Kültür Mirası'nın

1920- 2015 Arasında Geçirdiği Onarımlar ve Uğradığı Kayıplar", s.106) 